\title{
Popularizarea relativității lingvistice
}

\author{
Spiros A. Moschonas ${ }^{\mathbf{A} \mathbb{R}^{0} 8 \text { * }}$ \\ Departamentul de Studii ale Comunicării și Mass-Media, Universitatea Națională și Capodistriană din Atena, \\ 1 Sofocleous Str., 10559 Atena, Grecia
}

\author{
Despre articol \\ Istoric: \\ Primit 5 decembrie 2019 \\ Acceptat 4 mai 2020 \\ Publicat 10 iunie 2020 \\ Cuvinte-cheie \\ antropologie lingvistică \\ psiholingvistică \\ etnolingvistică \\ istoria limbii
}

\begin{abstract}
Rezumat
Lucrarea de față distinge trei faze ale popularizării relativității lingvistice: faza inițiată de Benjamin Lee Whorf însuși; o a doua fază, în care relativitatea lingvistică a fost formulată și testată ca ipoteză de cercetare; și faza curentă, în care afirmații întemeiate pe relativitatea lingvistică apar în mass media. Pentru a diagnostica răspîndirea acestui fenomen, am avut în vedere 560 de articole în engleză și greacă, apărute în presa tipărită și electronică. Articolele au fost publicate de-a lungul perioadei 2010-2019. Pot fi împărțite, nu absolut neechivoc, în optsprezece categorii. Unele dintre articole relatează explicit despre cercetări asupra relativității lingvistice, în timp ce altele, abordînd teme diverse-eficiența discursului managerial, justețea corectitudinii politice, posibilitatea de a comunica cu ființele extraterestre etc.—, operează implicit cu idei stimulate de relativitatea lingvistică. Numărul mare de categorii, precum și existența tacită a unor asemenea idei într-un număr crescînd de articole sînt indicatori ai gradului de popularitate atins de relativitatea lingvistică în discursul lingvisticii populare.
\end{abstract}

\section{Observații introductive}

„Numele lui Whorf a avut aceeaşi soartă cu a multor medici care au pus un diagnostic de boală revoluționar, în sensul că starea sau «boala » pe care a diagnosticat-o a ajuns să-i poarte numele, Whorfianism.” Așa grăit-a Silverstein (2000, p. 85).

Unicul scop al acestui eseu este acela de a ne face o idee despre cît de răspîndită este boala. Diagnosticul meu nu va avea în vedere boala, ci răspîndirea ei, cu dimensiuni deduse din texte apărute în presă, ce se ocupă de teme lingvistice care poartă fie amprenta, fie presupozițiile relativității lingvistice. A căuta presupozițiile unei idei oarecare în texte care se ocupă de acea idee sau care presupun acea idee estetrebuie să admitem—o procedură parțial circulară. Totuși, cel care va dori să descopere ceva într-un text nu se va împiedica de atîta lucru și, găsind ceea ce caută, se va simți destul de satisfăcut. Meritele textelor scrutate vor fi discutate în cele ce urmează.

S-ar putea ridica obiecțiunea că popularitatea unei idei nu poate fi diagnosticată decît dacă ideea este definită anterior, cu o anumită rigoare „științifică”. Într-adevăr, este necesară o definiție a relativităţii lingvistice, care să dea oricui posibilitatea de a căuta multiplele fațete ale relativității lingvistice într-un corpus ca cel avut în vedere aici și acum. Pentru scopurile noastre însă, o definiție operațională sau un ghid intuitiv care să ne sprijine în constituirea corpusului este îndeajuns. Încercarea de definire precisă a esenței noțiunii de relativitate este o capcană ce ar trebui evitată. Ideea în sine de relativitate este instabilă, suferă transformări pe măsură ce vorbim. La un moment dat în cursul diseminării ei, ideea s-a osificat, s-a simplificat; a devenit stereotipă, schematică, mai uşor de gestionat. A reprezentat aceasta Faza 2, cred eu, a unui proces continuu de popularizare a relativității lingvistice. Privită din perspectiva Fazei 3 (faza în care probabil că ne aflăm acum), faza aceea (Faza 2) iese în evidență prin următoarea simplificare: relativitatea lingvistică - sau relativitatea lingvistică per se-reprezintă ideea că fiecare limbă exprimă o perspectivă diferită asupra lumii; legată de aceasta apare ideea geamănă că limba determină gîndirea-determinism

*Adresă de corespondență: smoschon@media.uoa.gr. 
lingvistic. Așa este și continuă să fie prezentat relativismul lingvistic în cărțile de introducere în lingvistică (e.g., Lyons, 1981, p. 303-317; Fromkin, Rodman \& Hyams, 2011, p. 310-315; Baker \& Hengeveld, 2012, p. 354-357).

Există o ambiguitate intenţionată în expresia „popularizarea relativităţii lingvistice”. La origine, relativitatea lingvistică nu a reprezentat o noțiune de popularizat; mai degrabă, ea a funcționat ca noțiune popularizatoare. Cel mai celebru popularizator a ce va fi însemnat relativitatea a fost Benjamin Lee Whorf. Din prea-accesibila sa operă (Whorf, 1956), multe dintre cele mai inflente texte ale sale sînt scrise cu scop popularizator, adresate fiind ele unui public larg, nu doar unui cerc strîmt de lingviști, antropologi, boasiști (Darnell, 2001; 2006). Nu Whorf a venit cu ideea „relativităţii”-ea există, explicit, la Sapir, profesorul lui Whorf (de unde „ipoteza Sapir-Whorf”), și ar trebui numărată și printre principiile metodologice ale lui Boas, profesorului lui Sapir (O limbă ar trebui descrisă în propriii săi termeni).

În lingvistica modernă, ,arbitraritatea semnului” a lui Saussure (sau mai bine spus ,arbitraritatea relativă”) ar putea funcționa foarte bine ca termen alternativ pentru „relativitatea lingvistică”; cf. Benveniste (1939, p. 50-51) asupra „pensée historique et relativiste de la fin du xix ${ }^{\mathrm{e}}$ siècle”, "gîndirii historiciste și relativiste a sfîrșitului de secol XIX”, care se spune că l-a influențat pe Saussure ${ }^{1}$. Într-adevăr, Iluminismul francez și romantismul german mustiseră de idei de relativitate lingvistică (originile limbii, „spiritul” limbii, „climatul” unei limbi). Pînă și inospitalierul Ev Mediu, în materie de relativism, a cochetat cu ideea că limba poate fi folosită în convertirea necredincioșilor sau în cizelarea canonului moral al unei societăți ${ }^{2}$. Relativitatea nu s-a născut odată cu Whorf.

\section{Trei faze ale popularizării relativităţii lingvistice}

Relativitatea nu s-a născut odată cu Whorf, numai că el a fost cel care a botezat-„o”; și a scris teoretic despre ea. I-a dat un nume în auzul marelui public, inspirat de noțiunea relativității în fizică-deja populară la vremea aceea. Nu sînt sigur că plasarea intens-contestatelor rezultate ale speculațiilor lingvistice pe o poziție comparabilă în mod peren cu cea a faptelor demonstrate irefutabil de o știință tare ca fizica a reprezentat o acțiune înțeleaptă.

La urma urmelor, nu s-a înțeles niciodată ce anume era acel „ceva” pe care relativitatea lingvistică se străduia să-l popularizeze. După apariția lucrării lui Whorf (1956), relativitatea lingvistică (în continuare, RL) a devenit noțiunea de popularizat. Să spunem că aceasta a constituit faza a doua în popularizarea RL și că ea urma fazei întîi, a lui Whorf. Faza întîi își avusese originea în lingvistica antropologică, faza a doua izvora din psiholingvistică. Conform lui Pavlenko (2014, p. 14), ceea ce avea să fie cunoscut ca ,ipoteza Sapir-Whorf" (cele două idei gemene: relativitatea lingvistică per se şi determinismul lingvistic) ar fi mai bine să fie botezat „ipoteza Brown-Lenneberg” (v., e.g., Brown \& Lenneberg, 1954) 3 $^{3}$ În cursul acestei faze a doua de popularizare, RL s-a consolidat în arhicunoscuta dublă noțiune de relativitate lingvistică

\footnotetext{
${ }^{1}$ Saussure se apropie cel mai mult de formularea unui principiu al relativității lingvistice în Écrits de linguistique générale: „Nu gîndul este cel ce creează semnul, ci este semnul cel care ghidează fundamental gîndul” (Saussure, 2006, p. 27-28, unde 'fundamental'/engl. 'fundamentally' traduce 'primordialement'). Însă, dată fiind preocuparea lui Saussure în legătură cu „'essence double du langage”, este discutabil dacă această formulare trebuie interpretată în direcția a ceea ce noțiunea de relativitate lingvistică, apărută mai tîrziu, ajunge să însemne. Cît despre versiunea herderiană a relativității: Saussure s-a opus punctului de vedere potrivit căruia o limbă „caracterizează tipul mental al grupului social care o vorbește” sau „caracterul psihologic al unei națiuni” (Saussure, 1995, p. 312); și a avertizat împotriva tendinței de a considera că "geniul” unei rase are vreun efect determinant asupra limbii (p. 317). De asemenea, a avertizat împotriva „rezonabilei” ipoteze că mediul și clima afectează limba (p. 203).

${ }^{2}$ Pentru descrieri istorice, v. Miller (1968); Koerner (1992; 2002, p. 39-62); Penn (1992); Joseph (1996); Elffers (1996); Stam (1980); Darnell (2001, ch. 5; 2006); Leavitt (2011)—dar și Lee (1996). Există, se pare, două școli: unii istorici detectează originile whorfianismului în romantismul german; alții, limitîndu-se la „sursele imediate” ale antropologiei boasiene, refuză să facă la fel și trebuie să explice de ce. Astfel, ambele școli adoptă relativismul humboldtian/herderian drept cadru de referință. O expunere completă a istoriei evoluției RL, începînd probabil cu sofiștii, nu există. Sugestia rezonabilă a lui Bock (2003, p. 463) că Retorica III a lui Aristotel este un precursor timpuriu al RL este respinsă de Koerner (2002, p. 41), care crede că i-a găsit precursorul în Leibniz.

${ }^{3}$ Antropologul Harry Hoijer (1954) a fost probabil cel care a lansat expresia „ipoteza Sapir-Whorf”; cf. Koerner (2000).
} 
propriu-zisă și determinism lingvistic; și tot atunci a început să se dezvolte și metodologia-mai mult experimentală-de testare a RL ca ipoteză de lucru, în ciuda faptului (cred că este un fapt) că RL s-a vrut inițial a fi mai degrabă un termen-umbrelă pentru un set de observații lingvistice decît o ipoteză ce ar trebui demonstrată.

Roger Brown (1958, p. 229-231) s-a apucat să explice noțiunea de relativitate lingvistică pe fundalul unui punct de vedere opus, pe care îl considera prevalent în perioada aceea-sau cel puțin aşa pretindea: obiectivismul. Ceea ce „se crede la scară largă” despre limbă și gîndire, spune Brown, este că mesajul și codul sînt separate: cei mai mulți oameni, mai ales datorită învăţării limbilor străine, ajung să cocheteze cu „obiectivismul”: un fel de antonim al relativității. Obiectivismul era, conform lui Brown, „concepția populară", poate deoarece nu avea nevoie de justificare. Relativitatea juca rolul ratatului. Trebuie menționat că, ocazional, Whorf însuși a adoptat aceeași retorică (cf. Schultz, 1990), dînd impresia că apăra relativitatea împotriva prejudecăților ce domneau în tipul de gîndire dominant în vremea sa-gîndirea Medie Europeană Standard, poate.

Putem vorbi despre o a treia fază în popularizarea RL, care vine după popularizarea întreprinsă de Whorf și după popularizările popularizării, întreprinse de cei de teapa lui Brown și Lennenberg? Trăim cumva o nouă eră a „whorfianismului popular”? Convingerea mea este că, într-adevăr, RL trece printr-o nouă fază a popularizării. Dar înainte să aduc dovezi pentru afirmația mea, să ne oprim puțin asupra a ceea ce au de spus experții în această problemă, i.e. jurnaliștii lingvisticii.

McWhorter, în polemica și polemizabila sa lucrare The Language Hoax, insistă asupra unei distincții ce ar trebui făcută între whorfianismul academic și popular. Se înțelege că formațiunea verbală din expresia „limba dă formă gîndirii”” este folosită cu sensurile 'controlează, 'afectează', 'influențează, 'determină, 'constrînge', 'canalizează. În concepția lui, whorfianismul este ipoteza sau, mai bine zis, maxima că „limba dă formă gîndirii” (McWhorter, 2014, ch. 3). „Pur şi simplu, whorfianismul popular [...] nu este adevărat. Neo-whorfianismul academic este—să n-aveți nicio îndoială”, spune McWhorter, academicul (p. 48). Prin urmare, pentru McWhorter, whorfianismul academic este pur și simplu corect, iar whorfianismul popular este pur și simplu fals. Foarte convenabil, desigur: relativitatea în știință este o realitate; relativitatea populară în afara științei, dar avînd originea în aceasta, nu este. Dar whorfianismul popular nu este chiar atît de diferit de whorfianismul academic, fie și numai dacă ne gîndim că atîția profesioniști, începînd cu Whorf, au trecut ei înșiși la popularizarea propriilor observații asupra RL. În istoria ideilor lingvistice, RL este probabil singura constelație ideologică ce cunoaște granițe atît de estompate între lingvistica populară și cea profesionistă. Lucările publicate în categoria (RL2) de mai jos sînt un exemplu de cît de estompată este distincția dintre lingvistică și lingvistica pupulară în chestiunea RL.

Să încercăm însă a urmări linia de argumentație a lui McWhorter și să punem întrebarea: Cine sînt falsificatorii relativității științifice în discursul popular? Pentru McWhorter, whorfianismul popular este consecința unor „cărți populare, ca Don't Sleep, There Are Snakes (2008), a lui Daniel Everett, Through the Language Glass (2010), a lui Deutscher, intens-mediatizatele studii ale psiholoagei Lera Boroditsky de la Stanford, precum și a altor lucrări [care] au generat o memă whorfiană în discursul public” (McWhorter, 2014, p. xiv). Între cei citați de McWhorter, Everett este, în opinia mea, un relativist cultural: pentru el, limbile reflectă culturile—ceea ce nu reprezintă o dogmă întocmai cu „limbile constrîng gîndirea”. Deutscher este și el un fervent apărător al relativismului cultural și auto-proclamat istoric al lingvisticii; a venit la un moment dat cu următoarea caracterizare a lui Whorf: „cel mai notoriu dintre scamatori, Benjamin Lee Whorf, care a păcălit o generaţie întreagă să creadă, fără nicio urmă de dovadă, că limbile amerindiene i-au condus pe vorbitorii lor spre o concepție despre realitate total diferită de a noastră" (Deutscher, 2010, p. 21). Pe baza acestei afirmații singure, deduc eu, ar trebui să fie dat afară din clubul whorfianiștilor, dacă nu și din rîndurile academice. Boroditsky este o popularizatoare a muncii experimentale a sa și a altora asupra RL, și o face foarte bine-McWhorter ar trebui să o numere printre whorfianiștii academici.

John B. Carroll, editorul lui Whorf, folosește expresiile „problema Weltanschauung în lingvistică” în The Study of Language (Carroll, 1953, p. 43) și „,ipoteza Sapir-Whorf” în Introduction la opera lui Whorf(1956, p. 27). 
Întîmplător, din perspectiva zilelor noastre, și cartea lui McWhorter ar trebui inclusă în rîndul celor care au ajutat la generarea unei 'meme whorfiene', o situație pe care McWhorter însuși n-ar fi avut cum s-o prevadă.

McWhorter nu este un oponent al relativității, dar Pinker, care este, a făcut observația, în The Stuff of Thought (2007), că ipoteza Sapir-Whorf „de-a lungul primilor ani '70 [...] penetrase conștiința populară” şi că „a fost resuscitată recent” sub eticheta de neo-whorfianism: „au fost semnalate în media mai multe studii recente care și-au propus să arate că limba determină gîndirea” (Pinker, 2007, p. 128, 124-125). Observați că și McWhorter, și Pinker, prieten și dușman, privesc whorfianismul popular ca „ideologie dominantă”. Așadar, „obiectivismul” a încetat să mai fie dominant; poate că celor din stirpea lui Brown și Lennenberg ar trebui să li se recunoască contribuția în această schimbare de direcție ideologică.

S-ar putea spune că, dacă faza întîi a fost a lui Whorf și faza a doua a fost a whorfienilor, atunci faza a treia ar putea foarte bine să fie a „neo-whorfienilor”. Cine sînt însă acești „neo-whorfieni”? Există la ora actuală reluări importante ale operei lui Whorf și reformulări ale întregului său „complex teoretic” (Silverstein, 1985, 2000; Mertz \& Parmentier, 1985; Hill \& Mannheim, 1992; Lee, 1996; Leavitt, 2011; Pavlenko, 2014). Asemenea reevaluări au avut mai degrabă un efect deconstructiv, dezordonînd felul în care lingviștii înțelegeau relativitatea lingvistică. Nu felul în care este citit Whorf de către autorii respectivi este popularizat în media -și nici nu poate fi, de vreme ce ar fi dificil de urmărit. Probabil că termenul „neo-whorfieni” se aplică acelor cercetători care au încercat să reconfigureze tehnicile experimentale și să le aplice unor noi domenii (Lucy, 1992a,b; Gumperz \& Levinson, 1996; Pütz \& Verspoor, 2000; Niemeier \& Dirven, 2000; Levinson, 2003; pentru critică de ansamblu, v. Björk, 2008; Everett, 2013). Asemenea cercetări nu prea și-au găsit însă drumul spre media; și nu mulți dintre autorii lor își asumă numele de „neowhorfieni”. Dacă trebuie ca termenul „,neo-whorfieni” să fie rezervat pentru cei cîțiva experimentatori (cum sînt, probabil, Lera Boroditsky, Panos Athanasopoulos și destui alții) care își fac publicitate în presă, atunci așa să fie! Categoria (RL2) de mai jos conține texte mediatice care exemplifică recentele încercări ale lingviștilor și ale colaboratorilor lor de a verifica ,ipoteza relativității lingvistice” prin experiment sau prin studii de caz asupra vocabularului și gramaticii din diverse limbi. Dar a aplica termenul „neo-whorfian” numai acelor cercetători a căror muncă ajunge în presă sună a falsă acuzație. Popularizarea muncii cuiva este un demers cît se poate de onorabil, poate chiar o obligație a lingviștilor de meserie (Labov, 1982, p. 173); și, în timp ce faci educația maselor, de ce să nu cauți și puțină publicitate? Așa că poate că nu „neo-whorfienii” ar trebui făcuți responsabili de vulgarizarea pînă la denaturare a expresiei „relativitate lingvistică”, ci mai degrabă prezentările popularizatoare ale unora ca Pinker (2007), Deutscher (2010) și McWhorter (2014).

După cum vreau să arăt, particularitatea acestei a treia faze a popularizării RL nu este persistența relativității și a determinismului ca principii directoare. Ceea ce orientează întreaga paletă de publicaţii din categoriile (RLI) pînă la (RL I 8) de mai jos este vulgarizarea pînă la denaturare a noțiunii de RL în domenii adiționale, utilizarea ei presupoziţională și mai mult ca principiu implicit decît declarat. Categoria (RLi) include relatări generale asupra relativității, iar (RL2) include rapoarte asupra unor experimente și studii de caz specifice. RL poate fi însă observată și în alte tipuri de publicații, unde nu este explicit menționată. În această etapă a expansiunii sale, a treia fază în popularizarea RL, explicarea ideii nu se face împotriva unui fel oarecare de obiectivism, după cum a spus-o Brown, ci mai degrabă pe temeiul popularizărilor sale anterioare. RL devine ideologia „dominantă” în anumite chestiuni lingvistice-exact ceea ce au prevăzut prieteni şi duşmani deopotrivă, alde McWhort și Pinker.

\section{Un corpus de texte mediatice}

Un precedent pentru studiul expus în secțiunea de față se află la Mertz (1982), care a urmărit o „teorie populară” a RL într-un corpus de documente legislative din Statele Unite. Corpusul meu consistă din texte analogice și/sau digitale publicate în presa engleză și grecească (în continuare, de obicei, articole), care fie se ocupă de relativitatea lingvistică, în mod tematic, metalingvistic, fie o presupun doar, în timp ce 
abordează o chestiune lingvistică aflată în relație cu aceasta. (Am recunoscut deja circularitatea acestui criteriu implicat în constituirea unui corpus.) Numărul total de articole despre sau în legătură cu relativitatea lingvistică, avute în vedere, este de 570, cea mai timpurie fiind din 26 august 2010, iar cea mai recentă, din 7 ianuarie 2019. Toate cele 570 de articole au fost selectate dintr-un corpus mai amplu dedicat mai multor teme lingvistice, alcătuit din: 2651 de materiale apărute în perioada 2010 - 31.12.2015 (fără o arhivare sistematică), 5049 în 2016 (cînd s-a trecut la arhivarea sisematică), 2476 în 2017, 2666 în 2018 și 67 (în momentul realizării studiului curent) în 2019. Zelul s-ar putea să fi jucat un rol în atingerea acelui număr considerabil mai mare din 2016! În ambele corpora, republicările au fost păstrate. Interesant este că toate textele grecești din corpus reprezintă republicări (traduceri sau parafrazări, cu și fără permisiune) ale unor materiale din media de știri englezești.

Pentru constituirea corpusului am folosit, în ultimii ani, cîteva aplicaţii noi: Freedly, Microsoft News, Google News, News360, Flipboard. Toate aplicate mai ales la media din America; am folosit în respectivele aplicaţii cîteva combinații de cuvinte-cheie, fluxuri și ,interese” predefinite. În cazul textelor grecești, am preferat fluxuri de știri. Dincolo de aceasta însă, înțelegerea mea despre ce criterii de culegere și de stocare folosesc aplicaţiile în sine este destul de vagă. Admit deci că nu am avut control total asupra constituirii corpusului. Decizia în privința căror știri vor fi, în fapt, recepționate de cineva ține probabil de modalitatea obișnuită a fiecărui cititor informat de a se raporta la știri în era digitală. Dar starea aceasta de fapt poate genera și confuzie, deoarece cititorul nu are control real asupra textelor care i se livrează.

În Moschonas (2014) am descris metodologia alcătuirii unui corpus mai mic, tematic, extras dintrunul mai larg. Procentul textelor publicate despre RL în corpusul mai mic, raportat la numărul total de publicații pe teme lingvistice, este de 4,438561\% (falsă precizie? a rotunji la 4,44\% ar face figură suspectă). Desigur, nu este limpede ce anume măsoară acest număr, din moment ce un corpus mai mic reprezintă rezultatul aceluiași interes care ar determina rearanjarea pe criterii tematice a unui corpus mai mare. Totuși, pentru a da lingviștior o lecție de smerenie, ar fi de bun-simț să presupunem că articolele despre sau în legătură cu relativitatea lingvistică, în mediu analogic sau digital, nu reprezintă decît un mic procent din întreaga masă a articolelor pe teme lingvistice; iar acestea din urmă sînt și ele nu mai mult decît o fărîmă, în comparație cu masa articolelor pe teme non-lingvistice (cf. Moschonas, 2014, p. 398).

Articolelor din media oferă, ca să folosim expresia lui Nietzsche, o perspectivă „de la jumătatea urcușului" ${ }^{\prime}$ asupra ideologiilor lingvistice. Putem supraveghea terenul de dedesubt, fără a pierde din privire piscurile. Textele mediatice se adresează unui public mai larg, nu sînt împovărate cu tehnicalități academice, sînt mai digerabile decît pot fi cei mai mulți dintre lingviști. Deși adresate poporului, ele nu obstrucționează priveliștea spre profesioniștii din sferele înalte, care făuresc ideologii lingvistice in interiorul lingvisticii. $\mathrm{Nu}$ ne vom ocupa însă, aici, de traiectoriile comunicative ce leagă lingviști, gazetari și public.

Construirea unui corpus implică, inevitabil, un anume grad de decontextualizare a textelor, iar corpul acesta creat tinde să fie abordat ca text în sine. Este aceasta o eroare critică la ordinea zilei. Am putut observa că un corpus mai mic conține un număr suficient de specimene, ca și de categorii. De asemenea, că sînt acolo atît texte polemice, cît și texte care nu-și asumă o poziție anume; apoi, că există tot atîtea texte pro, cîte sînt cele contra relativităţii. Ideologiile se manifestă numai la plural, iar ideologiile privind relativitatea lingvistică—chestiune intens contestată—nu sînt o excepție.

Faimoasa clasificare animalieră a lui Borges conține următoarea categorie: „toate animalele incluse în prezenta clasificare”. Clasificarea mea riscă să fie mai poradoxală; conține toate acele categorii de articole neincluse în clasificarea de faţă. Adică, trei dintre categoriile prezentate mai jos, de la (RL I 5) la (RLi 7 ), sînt reprezentate în corpusul mai mic. Mai întîi, (RL I s): filmul SF Arrival (2016) a stimulat apariția mai

\footnotetext{
${ }^{4}$ Expresia (Von halber Höhe aus) este din „Welt-Klugheit” (Științta voioasă) a lui Nietzsche, în traducerea lui W. Kaufmann: „Do not stay in the field! / Nor climb out of sight. / The best view of the world / Is from a medium height”. In traducerea lui Nauckhoff: „Stay not where the lowlands are! / Climb not into the sky! / The world looks best by far / when viewed from halfway high”; în original: „Bleib nicht auf ebnem Feld! / Steig nicht zu hoch hinaus! / Am schönsten sieht die Welt / Von halber Höhe aus".
} 
multor articole care s-au apucat să popularizeze relativitatea lingvistică—noțiune-cheie în scenariul filmului (Moschonas, 2017); sînt apoi articole despre limbi extraterestre ficționale (con-langs); și relatări despre xenolingvistică. Numai cîteva, reprezentative, sînt incluse în categoria (RL I 5). Cît despre (RL I 6) -(RL I 7 ): nicio trecere în revistă exhaustivă a articolelor dedicate relativității lingvistice nu poate omite relativismul dur herderian prezent în unele media, de obicei în relație cu vreo limbă „națională”. Greaca modernă este un caz excelent. Despre naţionalismul lingvistic în Grecia (RLI 6) și despre idealurile monolingve din spatele prescriptivismului din Grecia și de aiurea (RLI 7 ) am scris în Moschonas (2004, 2009). În prezentul studiu voi avea în vedere doar cîteva articole reprezentative. Urmîndu-l pe Borges, nimeni nu trebuie să-și toarne cenuşă în cap dacă operează cu o clasificare construită în aşa fel încît să servească propriilor sale interese.

Sînt categoriile exclusiviste, i.e. există una și numai una pentru fiecare articol? Din punct de vedere conceptual, categoriile sînt interrelaționate, se suprapun, unele chiar ar putea fi considerate subcategorii ale altora. De exemplu, (RL2) conține instanțe particulare ale relativității lingvistice, care exemplifică mai generalele ori teoreticele abordări din (RLI). Discursul managerial (RL7), discursul prescriptiv (RLI6), corectitudinea politică ( $R_{7}$ ) sînt strîns legate între ele, din moment ce toate tipurile de discurs avute în vedere exercită o anumită putere corectivă și presupun ideea că limba modelează comportamentul. În ciuda suprapunerilor conceptuale, fiecare articol a fost plasat într-o singură categorie.

Au fost delimitate optsprezece categorii, după cum urmează (cu specimene și comentarii):

$\begin{array}{ll}(\mathrm{RLI}) & \text { Expozeuri de RL } \\ (\mathrm{RL} 2) & \text { Cazuri de RL } \\ (\mathrm{RL} 3) & \text { Bi/Plurilingvism } \\ (\mathrm{RL} 4) & \text { Limbi în pericol } \\ (\mathrm{RL} 5) & \text { Traducere } \\ (\mathrm{RL} 6) & \text { Cuvinte intraductibile } \\ (\mathrm{RL} 7) & \text { Corectitudine politică } \\ (\mathrm{RL} 8) & \text { Discurs managerial } \\ (\mathrm{RL} 9) & \text { Determinism invers }\end{array}$

(RLio) Discurs ideologic

(RLII) Metafore conceptuale

(RL I 2) Relativism al genurilor media

(RLi3) Relativism etimologic

(RL i4) Relativism cultural

(RLi5) Naționalism

(RLi6) Prescriptivism

(RLi7) Comunicarea cu extratereștrii

(RLI8) Referințe en passant

(RLI). Expozeuri de RL. Articolele din (RLI) reprezintă popularizări ale cercetărilor, sintetizărilor și evaluărilor produse de neo-whorfieni din académie.

Să privim la cîteva exemple. Articolul Does your language influence how you think (Grammar Girl, "Quick and Dirty Tips”, 22.11.2018; și în „Scientific American”, 30.11.2018) este o expunere „echilibrată” a RL; o apără împotriva contraargumentelor, prezintă cîteva studii frecvent citate (despre nume de culori, relații spaţiale, limbi ce cunosc categoria gramaticală a genului) și încheie în această notă:

cercetări de ultimă oră au pus în evidență, ici și colo, zone în care dovezile sugerează într-adevăr că trăsăturile intrinseci ale limbii pe care o vorbești pot schimba felul în care gîndești-dar într-o mică măsură.

Dimpotrivă, The Sapir-Whorf Hypothesis, al lui Richard Nordquist, din „ThoughtCo.", 27.10.2017 (revizuit în 01.11.2018) — text scris de către un „Profesor de engleză și retorică timp de 35 de ani”-, este în mod clar ostil față de RL. Cuprinde definiții, un rezumat istoric, critică și multe inexactităţi. Ambele texte sînt tipice pentru categoria (RLI).

Nu este limpede cui se adresează asemenea articole. Pot fi comparate cu intrările dintr-o enciclopedie. De asemenea, este irelevant cît de corect este prezentată RL în texte ca acestea. Și A mini study in metaphysics: How language creates us, de Chris Miller, un text mult mai puțin autoritar și foarte simplist, din „The University of Dayton Flyer News”, 25.02.2017, ține de (RLI). Din perspectiva popularizării, ambele tipuri de texte sînt interesante-eruditul și naivul一, ultimul poate chiar mai mult decit primul. 
Am dat exemple de texte ale căror autori sînt șovăielnici în a accepta „ipoteza” relativităţii lingvistice. Guy Deutscher (Does your language shape how you think?, in „The New York Times Magazine”, 26.08.2010) este mult mai puțin echivoc: „Habitudinile gîndirii pe care cultura le-a sădit în noi din pruncie modelează felul în care privim lumea și reacțiile emoționale față de lucrurile cu care ne întîlnim”. Ca indicator al popularităţii RL, trebuie menționat faptul că titlul non-presupoziţional (Does your language influence how you think?, [rom. „Limba pe care o vorbești îți influențează gîndirea”?], ibid.) este mai puțin frecvent decît titlurile presupoziționale: How the language we speak affects the way we think [rom. „Cum afectează limba pe care o vorbim felul în care gîndim”] (de Antonio Benítez-Burraco, în „Psychology Today”, 02.02.2017); How the language you speak influences the way you think [rom. "Cum influențează limba pe care o vorbești felul în care gîndești”] (de Neel Burton, în „Psychology Today”, 08.08.2018); How language shapes our perception of reality [rom. „Cum este percepția noastră asupra realității modelată de limbă”] (de Vivian Gang, în „Fast Company”, 28.07.2018); How has language shaped who you are [rom. „Cum te-a făcut limba ceea ce ești azi”] (de Esmeralda Bermudez, în „Los Angeles Times”, 14.06.2018); How has language shaped your world [rom. „Cum ți-a fost lumea modelată de limbă”] (de Esmeralda Bermudez, în „Los Angeles Times”, 08.07.2018).

Diferența dintre textele din (RLI) și cele din (RL2) constă în aceea că primele nu se concentrează asupra unor cazuri specifice, ci se mulțumesc cu rezumarea dovezilor la îndemînă ce susțin părerea generală: RL. Totuşi, există un inventar comun de cazuri pe care le exploatează aceste sintetizări. De exemplu, iată cum rezumă Lera Boroditsky descoperirile în legătură cu „felul în care limba modelează felul în care gîndim”, în conferința Ted pe care a susținut-o (Ted Nov. 2017; cf. Boroditsky, 2003):

V-am dat cîteva exemple despre cum poate limba să modeleze profund felul în care gîndim, în varii privințe. Limba poate, așadar, să aibă efecte considerabile, cum am văzut că se întîmplă în privința timpului și a spațiului; oamenii pot desfășura spațiul și timpul în cadre complet diferite unii faţă de alții. Limba poate lăsa urme cu adevărat adînci-ați putut vedea acest lucru în cazul numerelor. Faptul de a avea numerale în limbă, cuvinte pentru numere, deschide întreaga lume a matematicii. Desigur, dacă nu numeri, nu poți face algebră, nu poți face niciuna din acțiunile necesare pentru a construi o încăpere ca cea în care ne aflăm sau pentru a transmite online această conferință, nu-i așa? Mica scamatorie pe care o execută cuvintele-numere îți deschide accesul spre o lume cognitivă completă.

Limba poate, de asemenea, să aibă efecte foarte timpurii-cum este evident în cazul culorilor. Acestea reprezintă decizii perceptuale simple, de bază. De felul cărora luăm cu miile, mereu. Și totuși, limba este implicată și în acel mecanism, preocupîndu-se chiar și de aceste mărunte decizii perceptuale ale noastre.

Limba poate avea efecte considerabil de largi. Problema genului gramatical poate părea un pic prostească, dar genul gramatical se aplică tuturor substantivelor. Înseamnă că limba poate modela felul în care te gîndești la orice poate fi numit printr-un substantiv. Or, aceasta nu-i puțin.

Și, în final, v-am oferit un exemplu de cum este în stare limba să modeleze lucruri care au o anumită greutate pentru noi-idei precum vinovăţia și pedeapsa, ori memoria martorului ocular. Toate acestea sînt lucruri importante în existența noastră cotidiană.

Chris Weller, un „experimentat reporter de inovații”, relatează despre „absolut fascinantele descoperiri” expuse în conferința lui Boroditsky într-un fel și mai colorat: „timpul poate zbura în toate direcțiile”; „obiecte inanimate se fac stăpîne pe descrierile de gen ale persoanelor”; „cum numești o culoare determină capacitatea ta de a o percepe”; „structurile gramaticale pot orienta atenția detectivilor asupra anumitor detalii de la locul crimei" (A leading cognitive scientist reveals how language shapes your perception of gender, colour, and justice, în „Business Insider”, 07.11.2017). Conferința lui Boroditsky a fost-am eu impresiachiar bine primită. Ceea ce ajută la construirea punții dintre textele categoriei (RLI) și cele din următoarea categorie. 
(RL2). Cazuri de RL. Articolele din această categorie tind să fie mai la obiect. Se ocupă de experimente specifice sau de studii de caz. Unele dintre ele fac publicitate unor proiecte de cercetare, venind din partea profesioniștilor: este emis un comunicat, iar reporterul îl introduce în presă; sau cercetătorul însuși publică un raport asupra muncii sale.

„Limba îți influențează percepția culorilor, arată un studiu recent”-apare undeva (Olivia Goldhill, The language you speak changes the colors you see, în "Quartz”, 07.11.2018, cu referire la Maier \& Rahman, 2018). Limba controlează ce culori poți sau nu poți vedea, nu-i așa? [au fost traduse în limba română, fără tehnicalități filologice, titlurile-rezumat, relevante pentru discuția de față; n.tr., A.C.]—anunță un alt articol (de Scotty Hendricks, în „Big Think”, 10.01.2017, cu referire la Franklin et al., 2008). O apariție comună sînt rapoartele despre efectele relativităţii asupra percepției cromatice, temporale, spațiale, a genului. Nici problematica moralității nu este ratată, e.g.: a minți în a doua limbă este considerat un act mai comod sau mai dificil, în funcție de linia de cercetare pe care o popularizează textul publicistic respectiv ( $A$ minți într-o limbă străină este mai uşor, în „Science Daily”, 19.07.2018, cu referire la Suchotzki \& Gamer, 2018; a se compara cu Jaime Fraze, Nu poți minți - in limba ce nu-ți este nativă, în „From the Grapevine”, 31.08.2018, cu referire la Bereby-Meyer et al., 2018). Nu lipsesc notițele despre alte capacități considerate a fi afectate de limbă: Vorbitorii a diferite limbipercep muzica diferit? (în „MedicalXpress”, 24.02.2016, cu referire la Langus et al., 2016).

$\mathrm{Nu}$ toate aceste anunțuri vizează cercetări experimentale. În (RL2) intră și studii de caz în domenii lexicale specifice, privitoare la fenomene gramaticale sau la caracteristici funcţionale și pragmatice ale limbilor. Unele teme par a fi recurente în presă. În ciuda demitizării operate de Pullum (1991), „cuvintele eschimoșilor pentru zăpadă” continuă să aibă puls: vezi, e.g., David Robson, David Robson, There really are 50 Eskimo words for 'snow' [rom. „Cele 50 de cuvinte eschimose pentru 'zăpadă chiar există”] (în „The Washington Post”, 14.01.2013); și, ce să vezi?!, Cercetătorii afirmă că scoțienii dețin cele mai multe cuvinte pentru zăpadă (menționează Jill Lawless, în „Toronto Sun”, 24.09.2015), mai exact, 421 de cuvinte (Nick Winchester, Researchers for New Scottish Thesaurus Find 421 Words for Snow, în „Newsweek”, 24.09.2015).

Studiile de caz se întind pe o paletă largă, de la serioase pînă în măduva oaselor, pînă la ridicole. De pildă, studiile ce fac uz de „economia whorfiană” ar trebui privite, toate, ca demersuri de aplicare greșită a principiului relativității, pentru că încearcă să coreleze lucruri ce nu pot fi corelate. Numai că tocmai aceste cazuri atrag atenția în literatură și în media (e.g., Limba pe care o vorbești îți poate influența abilitatea de a te îmbogățti, de Kathleen Elkins, în „Business Insider”, 03.08.2015, cu referire la Keith Chen, Could your language affect your ability to save money?, Ted June 2012; v. și relevantele discuții de pe Language Log, cu răspunsul dat de Chen, aici). Următoarele sînt tot despre studii în legătură cu „economia whorfiană”, care se străduiesc să coreleze o trăsătură lingvistică, cum ar fi „exprimarea viitorului”, cu abilitatea de a lua decizii și/sau de a economisi bani, la nivel național sau global: Limba modelează perspectiva oamenilor asupra timpului și susținerea unor politici progresiste (de Melissa Heeke, în „American Journal of Political Science”, 25.01.2017); Felul în care utilizăm limba poate să ne decidă viitorul (de David Mas Masumoto, în „The Fresno Bee”, 27.02.2016). Primele cercetări ale lui Whorf asupra sistemului temporal la Hopi își găsesc ecoul în prezentări relativiste ale sistemelor temporale ca acestea din: Este percepția noastră asupra timpului influențată de limbă? (de Panos Athanasopoulos, în „The Wire”, 16.06.2017; reluat, printre altele, în Percepția pe care o ai asupra timpului s-ar putea să depindă de limba pe care o vorbești, în "The Sunday Times”, 08.05.2017); Felul în care mintea noastră concepe trecutul, prezentul și viitorul depinde de relația noastră cu timpul (de Sarah Duffy, în „The Conversation”, 03.01.2018); și tot așa. Pentru Whorf, sistemul temporal la Hopi fusese o fereastră spre „metafizica” la Hopi; pentru cercetarea recentă, sistemele temporale sînt concretizări ale unor tipare de gîndire distincte.

Trebuie precizat că în categoria (RL2) intră și articole dubitative față de unele studii ce emit pretenţia de a fi verificat ipoteza relativităţii lingvistice în legătură cu un oarecare fenomen lexical sau gramatical. Ca alternativă la teoriile relativiste despre culori, de exemplu, există articole ce pun accentul pe constrîngeri universale, e.g., Surprinzătorul tipar din spatele numelor de culori din întreaga lume (în „Open Culture”, 06.08.2018, cu referire la Berlin \& Kay, 1999). Cu folos ar fi și să urmărim discuțiile relevante, 
pe această temă, de pe Language Log; iată cîteva intervenții reprezentative: Geoffrey K. Pullum, „Keith Chen, un economist whorfian” (Language Log, 09.02.2012); Mark Liberman, „Răspîndire culturală și ipoteza whorfiană” (Language Log, 12.02.2012); Keith Chen, „Economie whorfiană” (Language Log, 21.02.2012); Mark Liberman, „Un candidat pentru prostia whorfiană nonșalantă a anului” (Language Log, 11.03.2018).

După cum am explicat deja, categoriile (RLI)-(RLI 8) sînt exclusiviste numai într-un sens forțat, arbitrar, de dragul clasificării. Suprapuneri ale categoriilor sînt firești. Grosul materialelor media din categoria (RL2) este reprezentat de studii ce urmăresc să arate efectele pe care le au diferite limbi asupra comportamentului; așa că articolele din (RL2) ating, direct sau indirect, problema bilingvismului sau plurilingvismului, tema următoarei categorii a noastre, $(\mathrm{RL} 3)$.

(RL3). Bi/Plurilingvism. Prefer să cred că articolele din această categorie formează un locus, un topos conceptual (Spitzmüller, 2005, p. 271; Spitzmüller \& Warnke, 1978, p. 191), mai degarbă decît că ele împărtășesc aceeași temă. Nu toate publicațiile despre bi/plurilingvism (tema) adoptă o poziție relativistă, însă bi/plurilingvismul este terenul fertil (locus) pe care poate se poate ridica poziția relativistă.

Să mă explic, comparînd pur și simplu două subclase de articole în categoria (RL3). Pe de o parte, sînt acele texte care promovează ceea ce se numește „,beneficiile bi/plurilingvismului”, beneficii în a căror largă gamă se prenumără amînarea demenței (Ellen Bialystock, The health benefits of bilingualism, în „goop”, f.d.) și aspectul sexy (Maureen O'Hare, Does being bilingual make you sexy?, în „CNN Travel”, 02.04.2017; cf. Learning a new language stimulates same pleasure centres in the brain as sex and chocolate, de Priya Joshi, în „International Business Times”, 25.10.2014). Nu toate articolele ca acestea adoptă în mod deschis poziția relativistă, deși niciunul nu este incompatibilă cu ea. Pe de altă parte, sînt acele texte care adoptă o poziție relativistă clară în chestiunea bi/plurilingvismului, e.g., Invățarea unei limbi noi scimbă modul în care percepi realitatea (de Ivan Miguel, în „Quartz”, 29.11.2017). Avantajul bilingv în acest caz este efectul relativist; este vorba de un avantaj perceptual, unul care are legătură cu gîndirea sau cogniția. Iar acestui avantaj perceptual, considerat acum a fi o abilitate ori un talent, i se face publicitate în mai multe texte: e.g., Despre cum a doua limbă potențează creierul (interviu cu Mark Antoniou, în „Knowable Magazine”, 29.11.2018; cf. Antoniou, 2019); 5 feluri în care bilingvismul te face mai deștept (în „K Blog”, 25.09.2017; republicat ca Despre cum bilingvismul te face mai deștept, în „Grammarly Blog”, 26.11.2018); Plurilingvismul este bun pentru minte - și corp (de Hans Pienaar, în „Business Day”, 12.06.2018); etc. Cîteva articole vădesc o atitudine similară față de bi/pluridialectalism: A vorbi mai multe dialecte ale aceleiaşi limbi este un lucru bun pentru creier (de Arika Okrent, în „Curiosity”, 06.09.2018).

Este interesant de reținut că media grecești este asaltată de articole similare (cele mai multe, adap-

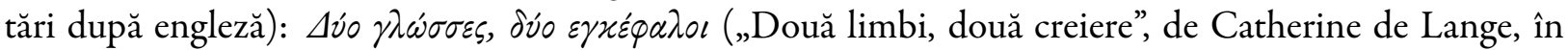

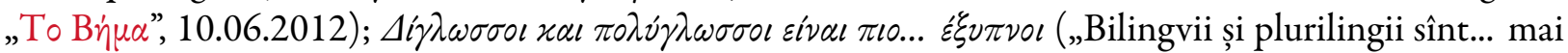

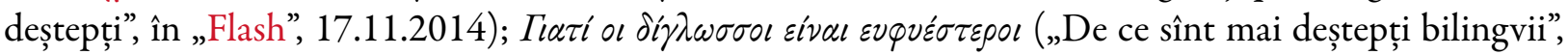
în „skepsou.gr”, f.d.); $\Gamma \nu \omega \sigma \tau \imath x o ́ ~ \varepsilon \rho \varepsilon ́ v ı \sigma \mu \alpha ~ \eta ~ \delta \varepsilon v ं \tau \varepsilon \rho \eta ~ \gamma \lambda \omega ́ \sigma \sigma \alpha$ („Stimulul cognitiv al celei de-a doua limbi”, în

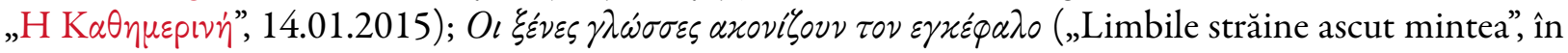
„Пр $\dot{\tau} \tau 0 \Theta \dot{\varepsilon} \mu \alpha ”, 13.01 .2015)$. Apariții ca acestea indică probabil migrarea, dinspre mentalitatea monolingvă, caracteristică pentru presa grecească în anii 1990 (Moschonas, 2001, 2004), spre o atitudine mai liberală față de bi/plurilingvism. Trebuie să ținem cont că bi/plurilingvismul nu a fost întotdeauna și peste tot atît de bine văzut ca acum. Poate că această re-evaluare a plurilingvismului este cea care își aruncă acum umbra asupra unor media care, tradițional, au favorizat ideologia monoglosică.

Dacă limba este cauza și mintea este efectul, se poate deduce care este avantajul cîștigat prin bilingvism, sintetizat în maxima: „două limbi, două minți” (expresie împrumutată de la Athanasopoulos et al., 2015; cf. Panos Athanasopoulos, How the language you speak changes your view of the world, în "The Conversation”, 27.04.2015). În articolul citat, este cuprins punctul de vedere al profesioniștilor; pentru punctul de vedere al lingvisticii populare, cf. expozeurile unei oarecare Simone Imurah, A Polyglot Mind (în „The Writing Cooperative”, 13.04.2018), care pretinde a fi o poliglotă pentru care „«Bună ziua! Mulțumesc! 
Iartă-mă și Îmi pare rău!» [...] sînt cuvintele magice în orice limbă”; cu toții sîntem poligloți, atunci.

Noțiunea de „minte bilingvă” sau cea de „creier bilingv” este, desigur, tema unor cercetări interesante (Javier, 2007; Hernandez, 2013; Costa, 2019), care au reprezentat baza re-evaluărilor lucide ale ideilor lui Whorf(Pavlenko, 2014); mă tem că nu prea mult material provenit din aceste cercetări apare în media. La fel, sînt ignorate și studiile care pun sub semnul întrebării avantajele bilingvismului. Presa englezească este de departe favorabilă bi/plurilingvismului-și, în fapt, mai mult plurilingvismului decît bilingvismului.

(RL4). Limbi în pericol. Și aici avem de-a face tot cu un locus, nu cu o categorie tematică, deoarece articolele ce o compun nu se ocupă de RL, dar par să o presupună, iar probabilitatea ca RL ori un concept legat de aceasta să fie menționată/menționat măcar o dată în interiorul celor mai multe dintre articole este mare. Menționările tind să fie formulate cam așa: Dispariția limbilor amerindiene afectează felul în care ințelegem lumea naturală (de Rosalyn R. Lapier, în „Salon”, 10.10.2018); When languages die, we lose a part of who we are (în „The Conversation”, 09.12.2015); Cînd o limbă moare, o perspectivă unică moare odată cu ea (afirmație din A way of understanding: When a language dies, a world dies with it, în „The RegisterGuard”, 31.12.2017); etc. Se pare că motivul „dispariția-unei-limbi = dispariția-unui-weltanschauung” funcționează și la nivel academic. Așa rezultă din faptul că David Harrison o spune în documentarul The Linguists (2008): „Cînd o limbă este amenințată, ne punem problema dacă nu cumva se va pierde un fel unic de a vedea lumea”.

Articolele din categoria (RL4) nu sînt doar despre limbi în pericol ori pe cale de dispariție, ci și despre limbi moarte, ca latina sau greaca veche, care se presupune că întruchipează o perspectivă unică, fertilă, perenă asupra civilizației umane; e.g., iată cum își prezintă Andrea Marcolongo propria carte din 2017un best-seller-, La lingua geniale: 9 ragioni per amare il greco: „il greco antico era un modo di vedere il mondo” [în italiană, în orig.: „greaca antică era un mod de a vedea lumea”; n.tr., A.C.] (Editori Laterza);

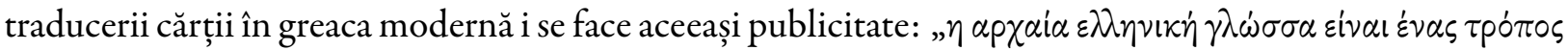

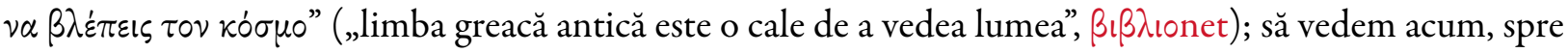
comparație, mult mai analitica descriere din ediția în engleză a cărții: „Fiecare limbă surpinde lumea întrun fel unic: cu cît este imaginea mai deosebită, cu atît este limba mai interesantă. Aceasta este ideea din spatele captivantei cărți a Andreei Marcolongo despre misterele limbii grecești vechi” (Editori Laterza). Un articol ce se apropie mult de cele din categoria (RL2) este acesta-preocupat de lexicul întrebuințat de greci pentru indicarea culorilor: Marea nu era niciodată albastră: experiența coloristică grecească era alcătuită din mişcare și tremur. Am putea vreodată să întrezărim ce vedeau [grecii] cînd priveau la mare? (de Maria Michela Sassi, în „Aeon”, 31.07.2017).

(RL5). Traducere. Din nou, un locus, mai mult decît o categorie. Nici din articolele acestei categorii nu lipsesc declarațiile de adeziune față de RL: Traducerea ne oferă o fereastră vitală spre fiecare limbă [în orig.: Translation gies us a vital windae intae ither warlds; n.tr., A.C.]—o spune ironic Ishbel McFarlane, într-o scoțiană reinventată (în „The National”, 01.11.2018). Motivul pentru care idei și atitudini legate de RL apar măcar în unele dintre articolele dedicate traducerii este acela că traducerea scoate la suprafaţă problema bilingvismului, a contactului, a medierii; și că traducerea reprezintă un mecanism ce poate portretiza relativiatea (să ne gîndim la „mecanismul glosării” al lui Whorf, prin ceea ce el numea „lexicări” [în orig., lexations; n.tr., A.C.]; cf. Silverstein, 2000, p. 92-93). Redau un fragment dintr-un interviu cu traducătoarea Daisy Rockwell (în „Language Chat”, 16.11.2018), exemplificînd obişnuitele dificultăţi cărora trebuie să le facă față un tarducător și ilustrînd procesul calibrării unei limbi prin cealaltă:

Fără îndoială, termenii de rudenie reprezintă, în opinia mea, cel mai dificil aspect al traducerii din limbi sud-asiatice în engleză. Literatura produsă de femei conține cu mult mai mulți astfel de termeni decît cea produsă de bărbați, pur și simplu pentru că, în general, mai multă acțiune se desfăşoară în interiorul casei decît în afara ei. Mă străduiesc cît pot să găsesc în limba engleză forme echivalente, dar uneori includ și termeni preluaţi din textul original, ca să nu fiu acuzată 
de traducere excesivă [în engl.: over-translation, n.tr., A.C.]. Firește, problema termenilor de rudenie nu ține doar de faptul că sînt foarte elaborați, ci și că sînt dependenți de context, astfel încît ceea ce este devar pentru cineva este bhai sahib pentru altcineva și chacha ji pentru un altul etc.

Fragmentul anterior este tipic, în opinia mea, pentru o serie de articole pe tema traducerii: se concentrează pe o problemă lingvistică locală (termenii de rudenie) ce iese la suprafață în procesul traducerii; pune accentul pe redarea formelor, mai mult decît pe lămurirea substratului lor conceptual sau cultural; și își propune să rezolve problema, într-un fel sau altul, pe tărîmul limbii-țintă. Contrar concepției generale, traducerea nu reprezintă un contra-argument la RL; poate fi o realizare a RL. Traducerea este o modalitate de „calibrare” (Whorf, 1956, p. 214) lingvistică reciprocă.

După cum era de așteptat, (RL5) conține și articole de tipul pierdut-în-traducere. Cu adevărat, este necesar să postulăm o subcategorie specială: cuvinte intraductibile.

(RL6). Cuvinte intraductibile. Spre deosebire de cele mai multe articole din (RL5), unde opiniile profesioniștilor contează, articolele din prezenta categorie sînt mai mult curiozități înfățișate publicului larg. Saudade (portugheză) și filotimo (greacă modernă) sînt două exemple de cuvinte „intraductibile”. Există destule articole de tip dicționar: 20 de cuvinte intraductibile în diferite limbi, care descriu emoții \& situații (în „Learning Mind”, 03.11.2018); 19 cuvinte uimitoare ce nu pot fi traduse (în „The Telegraph”, 04.06.2018); etc. Prin „cuvinte intraductibile” se înțelege, desigur, „intraductibile în engleză”. Cuvintele intraductibile sînt întotdeauna expuse alături de traducerea sau de parafrazarea lor: Cuvinte intraductibile (și traducerea lor) (de David Shariatmadari, în „The Guardian”, 21.08.2014). Cuvintele intraductibile sînt mistificate; se insinuează că faptul de a fi intraductibile implică ceva profund, deși nu este clar ce anume. Ceața care acoperă „intraductibilele” înseamnă, desigur, mister pentru omul de rînd, ca și pentru cercetătorul profesionist al conceptelor: cf. Cassin (2004). Se presupune că aceste cuvinte intraductibile ar revela ceva despre poporul care vorbește limba respectivă, o caracteristică națională (cum se presupune în cazul lui „filotimo”: v. Cuvîntul grecesc imposibil de tradus, de Stav. Dimotropoulos, în „BBC Travel”,

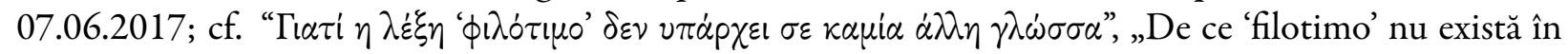
nicio altă limbă, în „Newsbomb”, 16.10.2015).

Mă voi opri asupra următoarelor cinci categorii, (RL7)-(RLI I), ca grup coerent. Voi explica mai întîi sistemul de relații creat între categoriile din grup, iar apoi voi da cîteva exemple din fiecare categorie.

Cele mai multe articole din grupul (RL7) - (RLI I) au de-a face cu aspectul performativ al RL-și, de asemenea, în același timp, cu cel ideologic: se referă la manifestări ale RL pentru care faimosul adagiu al lui J.L. Austin „a spune este a face” rămîne în continuare valabil; și, în aceleași timp, pun în evidență presupozițiile, credințele sau ideologiile care se află ascunse în discurs. Să luăm, de exemplu, corectitudinea politică (RL7). Ca practică lingvistică, corectitudinea politică exemplifică ambele dogme ale fazei a doua a relativității: determinismul și relativitatea propriu-zisă. Corectitudinea politică aspiră la idealul că cineva poate fi ajutat să-și modeleze gîndurile despre rasă, vîrstă, gen, sex (sau orice altceva) prin uzul potrivit al limbii. Avem aici, așadar, o puternică credință în determinism („limba modelează gîndirea”), exemplificată prin foarte corectiva practică a corectitudinii politice; care, în acelaşi timp, este revelatoare în privința valorilor, convingerilor, atitudinilor, ideologiilor etc. încifrate—se spune-în limbajul stigmatizat. Pentru că acceptă neechivoc determinismul, corectitudinea politică este asociată cu acele tipuri de discurs al căror scop este persuasiunea: de pildă, cu discursul managerial și de marketing din lumea afacerilor, cu cel al neuroprogramării, dar și cu cel al retoricii clasice (cu întreaga sa zonă de aplicabilitate); articolele grăitoare pentru aceste chestiuni aparțin categoriei următoare, (RL8). (RL7) și (RL8) au în comun o concepție managerială despre discurs. Dacă acest tip de discurs ar trebui să aibă un efect și să „determine” gîndirea indivizilor închiși în el, atunci este posibil și un soi de determinism invers, prin care limba este transformată în simptomul gîndirii care i-a fost impusă; de exemplu, felul în care cineva se exprimă poate 
fi un indiciu al rasismului și/sau al altor convingeri, sau al depresiei și/sau al altor trăsături ale respectivei persoane vorbitoare. Articolele care tratează limba ca simptom al unui mai larg sistem de gîndire apar în categoria (RL9). Relația dintre cele trei categorii este clară în acest moment: dacă determinismul este posibil (LR7-LR8), atunci este posibilă și indexicalitatea (RL9): dacă limba modelează gîndirea, atunci limba este un simptom al gîndirii. Ar fi mai potrivit să vorbim despre moduri sau sisteme de gîndire, sau sisteme ale minții, decît pur și simplu, în acest caz, despre gîndire. Asemenea sisteme de gîndire sînt plăsmuite în formele ideologiilor (RLIO) și ies la lumină prin analiza „metaforelor conceptuale” (RL I I), care nu sînt altceva decît simptome ale unui mod de gîndire (Lakoff \& Johnson, 1980). Să recapitulăm: ceea ce au în comun categoriile (RL7) - (RL I I ) este ideea că limba poate fi folosită în modalități care să ne constrîngă gîndirea (determinism) și că în limbă sînt sădite anumite moduri de gîndire ce se relevă prin analiza „conceptelor cu care trăim” (relativism propriu-zis). Simplu spus, relativitatea este văzută ca efect al determinismului.

$\mathrm{Cu}$ această introducere în chestiune, putem trece la prezentarea citorva exemple din fiecare categorie.

(RL7). Corectitudine politică. Deoarece privește rasismul, articolul acesta este, cred eu, reprezentativ, cu un titlul fără ambiguități în acest sens: Atenție: De ce folosirea termenului 'de culoare' este ofensatoare (de Amelia Butterly, în „BBC News”, 28.01.2015). Totuşi, este bine să reținem că țintele corectitudinii politice variază în funcție de convingerea sau ideologia persoanelor implicate în practica stigmatizării lingvistice. Să comparăm următoarele două materiale: mai întîi, Colegiu din Ariz[ona] denunță discurs al urii 'Alb'-alimentat (de Kaila White, în „USA Today”, 30.04.2015) este un text care relatează reacțiile „naționaliștilor albi și ale ‘predicatorilor urii”” la un curs despre „problema lui a fi alb”, ținut de Lee Bebout la Arizona State University. Mai este însă și acest material, din aceeaşi publicație, cam în aceeași perioadă de timp: Cum ne apare limba ca luptînd impotriva rasismului? (de Jessica Masulli Reyes, în „USA Today”, 06.12.2015); scris în urma împușcării mortale a unui adolescent negru de către un ofițer de poliție, articolul examinează meritele evitării utilizării „termenului 'supremaționist alb', cu conotații rasiale”. Să punctăm, în treacăt, că articolele din această categorie nu sînt neapărat corecte politic (deși cele mai multe sînt); ele sint mai degrabă despre corectitudinea politică.

Alte apariții în categoria (RL7), cu înclinaţie evidentă spre relativism, suprapunîndu-se parțial peste articolele din categoria (RL2), sînt cele despre sexism: e.g., Cum sint construite stereotipurile de gen in mandarină (în „The Economist”, 06.09.2018); Feminiștii declară că limba germană este sexistă (de Austin Davis, în „USA Today”, 09.07.2018); Este limba germană sexistă? (în „German Language Blog”, 29.08.2018). Sînt apoi mai multe texte despre pronumele insensibile la gen, e.g. Pronumele färă gen: Ce sînt \& cum să le folosim (de Caroline Forsey, în „HubSpot”, 28.09.2018). Reținem și că lingvista Deborah Cameron publică frecvent materiale lămuritoare despre sexism și discriminare lingvistică pe blogul ei, Language, $A$ Feminist Guide, cele mai multe încadrîndu-se în categoria de faţă.

$\mathrm{Cu}$ siguranță, rasimsul și sexismul, dacă ne luăm după cele expuse în articole ca acestea, reprezintă țintele obişnuite ale corectitudinii politice. Dar nu sînt singurele. Recent, PETA (People for the Ethical Treatment of Animals) — grup ce militează pentru drepturile animalelor-a somat populaţia să înceteze să mai folosească „expresii anti-animale”, precum „kill two birds with one stone” [rom., lit.: „(a) ucide două părăsi cu o (singură) piatră”] (alternativa sugerată ar fi "feed two birds with one scone” [rom., lit.: "(a) hrăni două păsări cu (singură) turtă”]) (PETA Asking People to Stop Using 'Anti-Animal Language, de Ashley Carter, în „Spectrum News - News 13”, 05.12.2018). Propunerea a fost întîmpinată cu dispreț [în orig., „with scorn”; n.\&s.tr., A.C.] (v., e.g., „PETA a uitat să corecteze aceste expresii anti-animale”, în "The Late Show with Stephen Colbert”, 06.12.2018).

(RL8). Discurs managerial. Iată cîteva mostre reprezentative: 5 modalități prin care pregătirea lingvistică îmbunătățește performanțele angajatului (de Melanie Rogers, în „ATD”, 29.11.2018); Studiu lingvistic indică cele mai bune cuvinte pe care să le folosești în vînzări (în „Science Daily”, 29.04.2016); Schimbă-ți 
cuvintele, schimbă-ți viața ${ }^{5}$ (de Tony Robins, în „Thrive Global”, 17.03.2017); Cum o simplă schimbare verbală ți-ar putea schimba viața (titlul original: Change a word, change your life, de Mel Schwartz L.C.S.W., în „Psychology Today”, 05.09.2018); etc.

Textele mediatice despre discursul managerial nu sînt numai despre comunicarea în lumea afacerilor; după cum o arată ultimele două exemple, unele apar sub eticheta 'dezvoltare personală. Prezentări (sau aplicaţii) ale PNL [„programare neuro-lingvistică”; în orig.: NLP, „Neuro Linguistic Programming”; n.tr., A.C.] intră și ele în această categorie: Fă schimbări pozitive de viață cu PNL (în „Excellence Assured”, 24.10.2017); 5 tehnici de PNL care să-ți schimbe viața (în „Sprouts Change”, 30.06.2017). „Puterea cuvintelor”, „puterea discursului pozitiv”, „cuvinte transformatoare” și alte expresii ca acestea tind să fie recurente în textele mediatice ale prezentei categorii. După Robins (op. cit.):

Aceasta este puterea a ceea ce eu numesc Vocabular transformator - să-ți folosești conștient cuvintele ca să-ţi îmbunătățești calitatea vieții de azi și pentru totdeauna.

Și iată cum explică Schwartz (op. cit.), în stilul său filozofic exaltat, de ce uzul verbului $a f i$ (și a altor verbe statice, ar trebui să adăugăm noi) ne zădărnicește posibilitatea de schimbare:

Teza unei realităţi obiective este înlocuită de o realitate subiectivă participatoare. Această nouă perspectivă asupra lumii pare a fi foarte caldă și comodă pentru oameni, din moment ce participarea umană transmite o informație către lume, iar noi nu ne mai percepem ca obiecte disparate. Ca să accesăm și să beneficiem de această nouă vedere a realității, trebuie să ne schimbăm limba pe care o vorbim, deoarece [formele verbale ale lui] a fi ne țin blocați în realitatea secolului XVII.

Cum s-a arătat mai sus, textele publicate din (RL8) se află în relație apropiată cu cele din categoria următoare.

(RL9). Determinism invers. Dacă avocaţii corectitudinii politice ori propovăduitorii oricărui tip de discurs managerial caută să influențeze imaginea despre lume și chiar viața cuiva convingîndu-și enoriașii să adopte noi obiceiuri lingvistice, lucrul acesta se întâmplă pentru că acești avocați și propovăduitori sînt siguri că în limbă este deja sădit un „mod de gîndire”. La fel stau lucrurile și în privința textelor mediatice din categoria (RL9). Acestea caută urme ale mentalităţii sau caracterului unei persoane ori a/al unui popor în limba pe care o utilizează. Sînt acestea cîteva exemple reprezentative: Căile ascunse prin care limba îți trădează caracterul (cu adaosul: De fiecare dată cînd deschidem gura, ne dăm arama pe față, fără să avem habar c-o facem, de Christian Jarrett, în BBC”, 21.07.2017); Oamenii în depresie folosesc limba altfel - Iată cum poți să-ți dai seama (în „The Conversation”, 15.04.2018). Trăsătura cutare de personalitate poate fi dedusă și numai pe baza markerilor fonologici: Cît de ADINNC $\breve{A}$ îți este iubirea? Vocile grave indică 'interesul sexual'și pot ajuta femeile să iasă in evidențăa, ne spun cercetările (de Colin Fernandez, în „The Daily Mail”, 19.12.2018).

Indexicalitatea discutată în aceste texte nu se leagă exlusiv însă de trăsăturile de caracter sau de personalitate. Să comparăm aceste exemple, diferite din punct de vedere tematic (şi nu uitați că, după cum v-am prevenit deja, exemplele variază de la serioase la dubioase): Cum problemele lingvistice îngreunează reacția in momente de criză-articol ce relatează un viol colectiv (în „The Economist”, 15.11.2018); 'Bătaie de inimă fetală vs. 'sarcină forțată: războaiele lingvistice ale dezbaterilor pe tema avortului-articol recent care ar putea fi plasat foarte bine și în categoria (RL7), supra (de Amy Harmon, în "The New York Times”, 22.05.2019; articolul nu fusese înregistrat în corpus de la început); Ne trebuie o nouă limbă ca să vorbim

\footnotetext{
${ }^{5}$ De asemenea, o carte cu același titlu, de Joyce Meyer (Hodder \& Stoughton, London, 2012). Există o uriașă literatură despre influențarea oamenilor prin limbă în scopuri economice; e.g., Sarah Myers McGinty, Power Talk: Using Language to Build Authority and Influence, Warner Books, New York, 2001; Murray Kevin, Language of Leaders: How Top CEOs Communicate to Inspire, Influence and Achieve Results, Kogan Page, London, 2012; Egnal Bart, Leading Through Language: Choosing Words That Influence and Inspire, Wiley, Hoboken, NJ, 2015.
} 
despre economie (de Tom Clark, în „The Guardian”, 19.02.2016) —articol ce aduce aminte de studiile de „economie whorfiană” din categoria (RL2); S-ar putea ca popularitatea veganismului să altereze limba ficțională-articol despre metaforele culinare, ce ar putea să apară și în categoria (RL I I) (de Shareena Z. Hamzah, în „The Conversation”, 22.11.2018); Studiu al mărcii de lenjerie feminină [X] dezvăluie cuvîntul de care femeile se tem cel mai tare (în „Cision”, 30.07.2015); ori să ne oprim asupra acestei meme cu circulație largă, de a cărei origine nu sînt sigur ${ }^{6}$, care pare să sugereze faptul că femeile cunosc mai multe nume de culori decît bărbații deoarece—ne dăm seama dacă apelăm la stereotipul potrivit—femeile sînt mai „vestimentar-conștiente” decît bărbaţii:

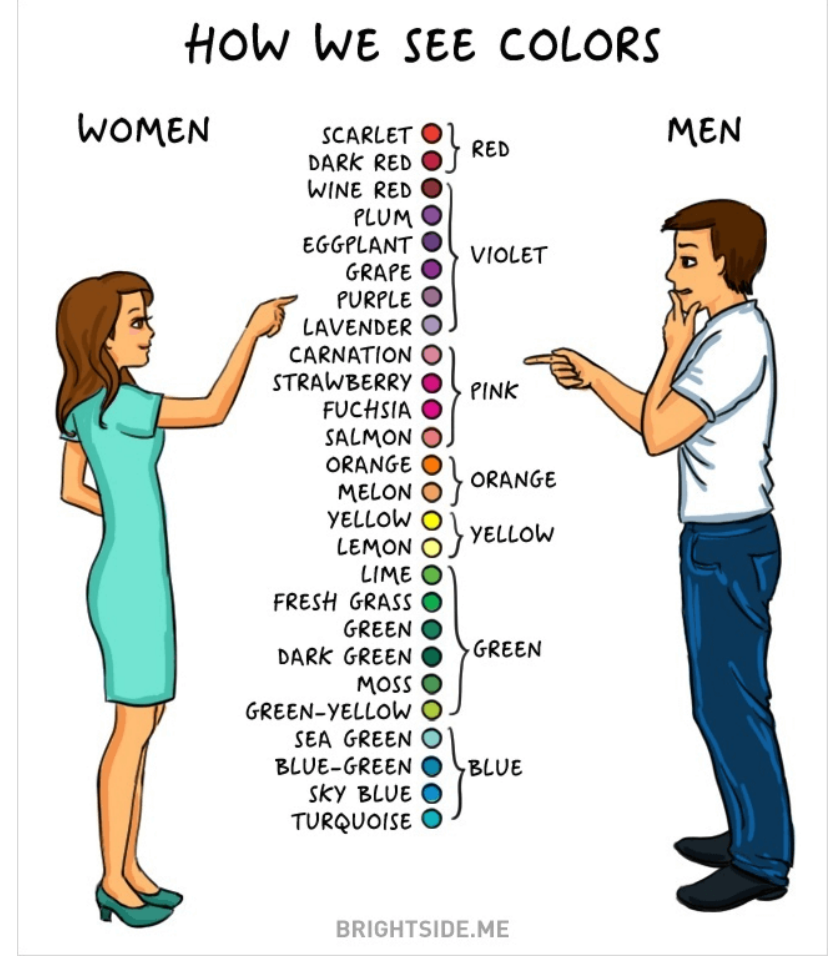

Pînă și Pinker, care, după cum am văzut, este ostil ideii de RL, pare să accepte un anumit tip de determinism invers: Steven Pinker de la Harvard: Cum vorbim revelează ce gîndim (în „Big Think”, 02.04.2015)7.

(RLIo). Discurs ideologic. 'Limba X-ului' este o construcție metonimică („limba mass mediilor”) sau analogică („limba artelor”) foarte comună. Cînd X se întîmplă să fie o ideologie, politică ori de altă natură, 'limba X-ului' se referă, prin determinism invers, la tiparele de gîndire (sau valori, sau ,ideologeme”) ale respectivei ideologii, indexate în discurs. Iată două exemple de acest tip: Limba stîngii (de Joseph Carli, în AIMN, 01.12.2018); Limba neoliberalismului (de Jason Hirthler, în „, Counterpunch”, 25.10.2013). Tiparul limba-contrînge-gîndirea este evident și în: Cum schimbă limba perspectiva asupra conflictului israeliano-palestinian din Gaza (de Randa Abdel-Fattah, în „The Sunday Morning Herald”, 18.07.2014); Lingvistica îi poate ajuta pe conservatori și liberali să se reconcilieze în privința realității obiective (de Tom Syverson, în „Quartz”, 23.02.2017) $)^{8}$.

${ }^{6}$ Cf. Cînd vine vorba de culori, femeile \& bărbații nu au aceeași ochi [în orig.: When it comes to color, men \& women aren't seeing eye to eye] (de Jordan Gaines Lewis, PhD, în „Psychology Today”, 08.08.2015)—articol potrivit și în categoria (RL2).

7 Un titlu mai bun pentru discuția aceasta ar fi Cum vorbim revelează cum gîndim. Este interesant că argumentul pe care Pinker îl aduce împotriva RL este că RL identifică limba cu gîndirea: „nimeni nu crede că limba este acelaşi lucru cu gîndirea și că toată viața noastră mentală constă în a recita enunțuri”; cf. Pinker (1994, p. 57 seqq.), unde susține că „ideea că gîndirea este același lucru care este limba este [...] o convenție absurdă”. Numai că nimeni nu a pretins vreodată că limba și gîndirea sînt același lucru; dimpotrivă, pentru ca limba și gîndirea să se coreleze, ca în „ipoteza Sapir-Whorf”, este necesar ca ele să fie menținute separate.

${ }^{8}$ Presupunerea relativistă că ideologiile sînt cumva sădite sau înrădăcinate în limbă este destul de răspîndită și în cercurile 
(RLI I). Metafore conceptuale. 'Metaforele conceptuale' (Lakoff \& Johnson, 1980)—sau, mai general, 'conceptualizările'-reprezintă exact ceea ce se revelează la analiza ideologiilor, valorilor, cadrelor mentalitare ori tiparelor de gîndire. De aceea, categoriile (RLIO) și (RL I I) sînt atît de apropiate. Avem cîteva exemple: Metaforele ne pot schimba opiniile în modalități de care nici nu ne dăm seama (de Steve Rathje, în „Quartz”, 31.03.2018); Război contra metaforelor inş̧elătoare! (de H.J., în „The Economist”, 21.07.2016, unde metafora războiului este utilizată în războiul declarat contra metaforei războiului); 6 idei preconcepute ascunse în cuvintele de zi cu zi (Iar tu nici n-ai băgat de seamă) (de Michael Dawson, Mike Bedard \& Dan Hopper, în „Cracked”, 21.11.2017). Unele dintre aceste articole se referă la celebrul studiu despre „boala ca metaforă”-la modă după Sontag $(1978,1989)$.

În categoriile (RLI ) - (RL6) am introdus texte mediatice care relatează despre felul în care „limba constrînge gindirea”. În categoriile (RL7)-(RLI I ) am văzut exemple de articole care se concentrează asupra felului în care „limba indexează gîndirea” prin determinism invers. Următoarele două categorii au în vedere modalități diferite prin care limba afectează gîndirea: genuri publicistice noi, în cazul grupei (RLI 2), și etape mai vechi într-o limbă, în cazul grupei (RLI 3$)$.

(RLI 2). Relativism al genurilor media. Moschonas (2001) demonstrează că presa scrisă grecească din perioada 1999-2001 are tendința de a pune comunicarea mediată de calculator într-o lumină proastă, cu scopul de a crea o panică morală în legătură cu iminenta amenințare a limbii grecești de către noile media; Thurlow (2006) ajunge la aceeași concluzie după ce examinează articolele de știri despre limba engleză, din perioada 2001-2005; și constată că evaluarea negativă a noilor genuri media „se îngemănează” cu îngrijorarea față de ,inabilitatea comunicativă a tinerilor”. În corpusul alcătuit pentru studiul de față, am avut în vedere numai materialele publicistice care scriu despre un efect oarecare al textelor din nou-apărutele genuri media, nu neapărat unul negativ. Iată un eseu general-expozitiv din această categorie: Cum schimbă media felul în care gîndim (în „Forbes”, 07.11.2017). Iar acesta este un exemplu de articol care se preocupă de comunicarea prin SMS [în orig.: texting; n.tr., A.C.]: Cum comunicăm prin SMS spune multe despre personalitatea noastră (de Ashley Carman, în „The Verge”, 09.11.2018; am putea plasa acest articol și în (RL9), supra). Deși în această categorie intră destul de multe texte tehnofobe, am impresia că noile genuri media nu mai sînt prezentate în lumina negativă care a dominat începutul de secol. Dezbaterea publică dacă sau nu Codificarea digitală ar putea satisface nevoia unei limbi străine în școlile din Florida (în „WFLA”, 12.02.2016) demonstrează că, cel puțin pentru o parte din instructori, o limbă digitală ar putea fi un substitut pentru una naturală—gîndire metonimică/analogică pusă în evidență și de textele publicistice din categoria (RLI I).

(RLI3). Relativism etimologic. Am creat această categorie pentru a așeza aici mai ales acele texte care comit așa-numita eroare de judecată etimologică, i.e. susţin că „adevărata” semnificație a unui cuvînt sau a unei expresii poate fi înțeleasă numai dacă se ține seama de sensul etimonului acestuia/acesteia; v., e.g., The etymology of 'orange': Which came first, the color or the fruit? [lit.: „Etimologia lui 'portocală': Ce a fost mai întîi, culoarea sau fructul?”] (de Jason Kottke, în „Kottke.org”, 02.08.2018). Nu sînt sigur dacă aceasta este o categorie corect construită, întrucît pare să contrazică relativismul istoric asociat adesea cu antropologia boasiană; v. însă Pot ideile să supraviețuiască transformărilor din limbă? Asupra ipotezei SapirWhorf in traducere, emoji și cultura pop (de Elisa Gabbert, în „Guernica”, 11.03.2016), unde se discută

academice. Ideologia este frecvent prezentată ca „filosofie implicită” în activitățile practice cotidiene (o „filosofie a praxisului”, spune Gramsci). Unii dintre analiștii critici ai discursului folosesc exact această metaforă, i.e. că ideologia este, ,înrădăcinată” în limbă; e.g., Fairclough (2001, p. 2, 14) crede că ideologia este „ubicuă în limbă” și vorbește despre „proprietățile ideologice” ale limbii. Ideea că o ideologie este sădită în limba însăşi nu trebuie confundată cu ideea că o ideologie este cu necesitate implicită, tacită ori presupozițională; cf. Mertz (1982, p. 4) cu referire la RL: „Teoriile populare sînt tacite; lanțul implicaţional [...] care le leagă nu este explicit formulat. Teoriile populare conțin și un fel de logică internă [...]. Totuși, aceasta nu înseamnă că teoriile populare sînt cu necesitate consistente din punct de vedere logic". 
despre chestiuni ce se potrivesc şi categoriei (RLI2).

Acum, pentru că ne apropiem de sfîrşit, să vedem mai pe scurt ce se întîmplă în cazul categoriilor rămase.

(RL14). Relativism cultural. Existența separată a acestei categorii mi s-a impus din nevoia de a diferenția relativismul cultural de RL. Relativismul cultural apare adesea ca alternativă la relativitatea lingvistică (e.g., la Deutscher, 2010). Prin relativism cultural înțeleg ideea că limbile „reflectă” cultura, nu atît că ,întrupează” tipare de gîndire. Mecanismele relativismului cultural și ale RL sînt, firește, aceleași: determinismul invers și indexicalitatea. Se presupune că în limbă găsim „imprimările” culturii și „urmele” habitudinilor de gîndire. Totuşi, interconectatele idei că limba „reflectă” cultura, că aceasta este „filtrată” prin „purismul” unei limbi, că o limbă este „calea” sau „fereastra” spre o altă cultură, că în limbă este prezervat spiritul unui popor etc. sînt asociate în primul rînd cu relativismul cultural ${ }^{9}$.

Există o suprapunere considerabilă între textele mediatice din această categorie și cele din categoria (RL4). Dăm cîteva exemple: Sensibilitatea culturală și valoarea învățării unei limbi (de Amelia Rose, în „The Argus”, 31.10.2018); Limbă și cultură (de Karen Sternheimer, în „Everyday Sociology Blog”, 08.10.2018). Ambele articole citate au în vedere învățarea limbilor străine. Următorul este despre o particularitate culturală ceva mai specifică: Cum mirosim? Teribil! Resursele de hrană s-ar putea să afecteze felul în care descriem mirosurile (de Nicola Davis, în „The Guardian”, 18.01.2018).

Pentru categoriile (RL I 5 ) și (RL I 6), aflate în relaţie, care solicită o analiză separată și mult mai amplă, trimit la lucrări precednte (Moschonas, 2001; 2004; 2009).

(RL I 5). Naționalism. Articolele din (RL I 5 ) prezintă ceea ce este frecvent numit „relativism herderian”, o varietate mult mai puternică de relativism whorfian. Relativismul herderian este asociat cu naționalismul. Poate fi studiat ca două concepții majore: aceea că „fiecare limbă are sau este un spirit aparte” și aceea că „fiecare limbă are sau este un teritoriu—real sau imaginat”. Această concepție teritorială despre limbă a ghidat presa grecească pe diverse teme lingvistice pentru multă vreme (Moschonas, 2004). Concepția teritorială nu se manifestă atît de mult în Anglia sau în Statele Unite, dar pare să fie dominantă în comunitățile în care se defășoară conflicte lingvstice. Interesant, în ambele articole citate mai jos, naţionalismul urmează, drept corolar, relativismului.

Iată un text de opinie din „The Hindu”, pe care l-am selectat pentru principiul deschis relativist din titlu: Limba nu doar oglindește lumea. Limba o face (de Mini Krishnan, în „The Hindu”, 23.06.2018): articolul este o pledoarie pentru necesitatea de a fi predată în școli o limbă regională în plus, care să contrabalanseze influența englezei.

Al doilea exemplu este un material preluat de pe un blog grecesc. Autorul discută, printre altele, despre vocabularul cromatic a diverse limbi, pentru a demonstra cît de strînsă este legătura dintre limbă și vorbire. Și emite ideea că realitatea noastră este fabricată de către limbă. Încheie apoi cu următoarea afirmație non sequitur:

Cei care nu se consideră membri ai unui grup etnic, care nu recunosc continuitatea naţională și

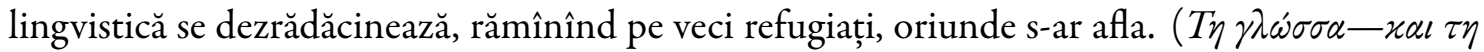

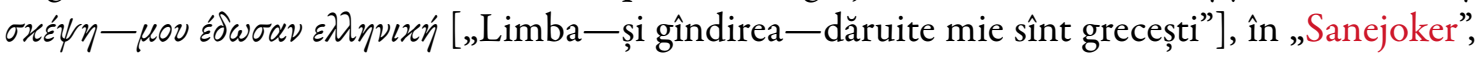
26.12.2015).

\footnotetext{
${ }^{9}$ Relativismul cultural este interpretat adesea ca etică a comunicării. Pentru McWhorter (2014, p. 45), „impulsul dominant al whorfianismului popular este de a scoate în evidenţă feluri în care alte societăți sînt superioare celei vestice: sînt mai conștiente de căi alternative de cunoaștere, sînt mai puțin cuprinse de obsesia viitorului, mai conștiente de topografia proprie, mai sensibile la sursele de informație”. „Entuziasmul whorfianismului popular”, conform lui McWhorter (2014, p. 53), „este înrădăcinat în ceea ce ar putea fi declarat și impuls religios, adică, credința pe care gîndirea omului modern o jură prețuirii, îngrijirii și protejării diversității, în locul respingerii ei”. Profilul moral al „whorfianistului popular” pe care îl schițează McWhorter se potrivește mai bine, cred eu, relativistului cultural.
} 
(RL16). Prescriptivism. Prescriptivismul, cu deosebire cel de natură puristă, este susținut de naționalism. Menționez aici doar un exemplu de text ce relatează despre interdicția impusă de l'Académie française față de aşa-numita „l'écriture inclusive” (expresiile fără marcă de gen), a cărei utilizare a devenit o temă majoră în presa franceză spre sfîrșitul anului 2017: „[l'écriture inclusive] pune limba franceză în «pericol de moarte», susține l'Académie française” (de Thomas Godard \& Olivia Walsh, în „The Conversation”, 15.11.2017).

(RL17). Comunicarea cu extratereștrii. În 2016, filmul SF Arrival a stîrnit un șuvoi de texte în presa tipărită și electronică. Filmul, bazat pe nuvela lui Ted Chiang Story of your life, este despre o lingvistă care primește din partea armatei misiunea de a descifra o limbă extraterestră. Lingvista pune la bătaie tehnici de teren și reușește să descifreze limba ființelor extraterestre descifrîndu-le mai întîi modul de gîndire; iată deci relativitatea lingvistică. Jessica Coon a funcționat ca lingvistă-consultant pe platourile de filmare și oferă o listă cu articolele despre film și despre importanța în scenariu a RL, aici: Arrival: Activitatea lingvistică de teren pe marele ecran”; cf. Moschonas (2017). Dacă pentru nimic altceva, cazul lui Arrival este grăitor pentru cît de estompată este distincția dintre lingvistica populară și cea profesionistă.

(RLI 8). Referințe en passant. În evaluări de natură estetică, e.g. în prezentări de carte sau de artă, sint deseori strecurate trimiteri la RL. Categoria (RL I 8) ar putea fi folosită însă și pentru a acoperi toate acele referințe la RL care nu au putut fi incluse în categoriile discutate anterior. Cineva ar putea crede că asemenea referințe sînt de mică importanță. Dar lucrurile ar putea foarte bine să stea exact pe dos. Dacă am dispune de o măsurătoare precisă a referințelor en passant, atunci am putea estima cît de cît acurat cît de răspîndită, echilibrată ori încărcată de prejudecăţi a devenit această idee care continuă să răsară acolo unde te aștepți mai puțin.

Închei expunerea acestor categorii (și a referințelor la RL en passant şi neștiute de nimeni) cu un fragment din My Shakespeare al lui Kate Tempest. Textul (mai bine văzut decît citit) arată cît de presupozițional a devenit stilul lingvistic al lui Shakespeare; este vorba despre un autor devenit limbă; este despre RL.

cuvintele lui sînt scena poveștilor noastre-a devenit un poet a cărui poetică s-a inserat adînc în țesătura limbii noastre, e în gurile noastre, cuvintele lui s-au încîlcit în jurul alor noastre și nasc expresii ce spun bine ce simțim, n-am ști cum ne-am simți de n-ar fi ele.

\section{Rezumat și concluzii}

Popularizarea RL este un proces care a început cu Benjamin Lee Whorf însuşi. A fost aceasta faza întîi a popularizării RL. Faza a doua a continuat cu formularea, testarea RL ca ipoteză de lucru—,,ipoteza SapirWhorf”-și consolidarea ei în forma a două principii, cel al determinismului și cel al relativității propriuzise. Lucrarea de față a urmărit cea de-a treia fază, curentă, a popularizării RL. Datorită noilor media, popularizarea este acum posibilă la scara maselor.

Pentru a vedea cum este concepută RL și cum se vorbește despre ea în discursul popular, am examinat un corpus de texte metalingvistice care fie sînt explicite în legătură cu RL, fie vădesc, fără să își propună acest lucru, unele caracteristici ale RL. Toate textele sînt disponibile pe internet, chiar dacă sursa multora dintre ele este presa tipărită.

Am separat textele publicistice în 18 categorii, (RL I )-(RLI 8). Eseurile expozitive (RL I) și prezentările de studii de caz (RL2) sînt în mod explicit despre RL. Celelalte categorii conțin texte care relatează ori emit opinii despre diverse chestiuni lingvistice din perspectiva RL, fără să fie nevoie să și conștientizeze acest lucru. Cîteva categorii-(RL3) despre bi/plurilingvism, (RL4) despre limbile în pericol, (RL5) despre traducere și (RL6) despre cuvintele intraductibile—pot fi văzute mai bine ca topoi, ca loci unde se manifestă urme ale RL. Simpla existență a unor loci ca atare demonstrează că RL este principalul mijloc de conceptualizare 
a temelor relevante. Categoriile (RL7) despre corectitudinea politică, (RL8) despre discursul managerial, (RL9) despre determinismul invers și indexicalitate, (RLIO) despre discursul ideologic și (RLI I) despre metaforele conceptuale formează un grup coerent de materiale despre mecanica RL. RL este prezentată fie ca practică de comunicare-( RL7) și (RL8)—cu efecte asupra atitudinilor sau a modului de gîndire ale/al recetorului, fie, pe calea determinismului invers, ca tipar lingvistic cristalizat (Whorf ar fi folosit expresia „fel de a vorbi”) ce indexează atitudinile sau modul de gîndire ale/a emițătorului-(RL9) pînă la (RL I I). În următoarele două categorii, textele mediatice comentează pe marginea tiparelor lingvistice relativizate față de noile genuri media (RL I 2) și totodată față de sensurile istorice ale repectivelor tipare lingvistice (RL I 3). Un alt grup de texte are de-a face cu relativismul cultural (RL I 4), naționalismul (RL I 5 ) și prescriptivismul (RLi6) - deși admitem că acestui grup nu i s-a dat aici atenția pe care ar merita-o. (RL 17), comunicarea cuființe extraterestre, este o categorie orfană; ar putea funcționa însă ca subcategorie a (RL2), un alt studiu de caz, în funcție de speranța pe care cineva și-ar pune-o în xenolingvistică sau în funcție de cît de îndreptățiți sîntem în a trata o limbă imaginară sau nemaiîntîlnită ca și cum ar fi, pur și simplu, o altă limbă.

Textele mediatice pe care le-am studiat (publicate în presa tipărită și digitală) oferă o „priveliște de la jumătatea urcuşului” a RL. RL reprezintă într-adevăr un punct unde se întîlnesc ideologiile profesioniste și cele populare despre limbă. Nu am putea înțelege adevărata forță a RL dacă ne-am închide în aria lingvisticii. $\mathrm{Nu}$ am pierdut din vedere cît de prost pregătit, gol de informație ori chiar stupid se arată a fi discursul despre RL, în mass media. Dar nici nu am ignorat faptul că, în cazul RL, discursul mediatic își are originea în discursul academic.

Categoriile cu ajutorul cărora am examinat RL în discursul popularizat și/sau popularizator nu coincid —sau coincid numai parțial—cu ceea ce Lee (1996) numește „complexul teoriei Whorf”, alcătuit din douăsprezece „elemente” sau părți; ele nu coincid—sau coincid doar parțial—cu a lui Silverstein (2000, p. 98-101) reconstucție în șapte părți a felului în care, conform lui Whorf, conceptele culturale apar în limbă. Și cu siguranță nu coincid cu pripitele schițe de whorfianism popular executate în lucrările virulente ale unor scriitori de teapa lui McWhorter, Deutscher sau Pinker. Dificultatea demersului a constat în aceasta: pentru a ajunge să recunoaștem presupozițiile RL, este nevoie să acceptăm drept cadru de referință literatura academică de ordin secundar asupra RL, cunoscînd pericolul de a fi pierdut din vedere presupozițiile sădite în RL „din afară”; însă tocmai aceste influențe care vin „din afară” au contribuit la transformarea RL într-o ideologie comună, o „mișcare populară” — sau o pandemie. Într-adevăr, în categoriile care formează grupul de mijloc $\left(R L_{7}\right)-\left(R L_{\text {I I }}\right)$, RL pare să funcționeze ca ideologie nebăgată în seamă dar dominantă (în sensul lui Abercrombie \& Turner, 1978), atît în interiorul cît și în afara académiei. Este în zilele noastre ideologia de serviciu în chestiuni legate de analiza (critică) a textelor.

RL este o fereastră înspre ceea ce este diferit. Procură niște lentile prin care se poate privi la aspectele unei limbi nefamiliare. Din acest motiv, popularizarea relativităţii lingvistice este pur şi simplu o altă modalitate de calibrare, alături de traducere, glosare ${ }^{10}$ sau stricta exegeză lingvistică. Să ne amintim ce spune Whorf (1956, p. 214) despre calibrare:

niciun individ nu este liber să descrie natura cu imparțialitate absolută, ci este constrîns să adopte anumite moduri de interpretare, chiar și atunci cînd crede despre sine că este cu desăvîrșire liber. Cel mai aproape de această stare de libertate ar fi un lingvist familiarizat cu foarte multe sisteme lingvistice foarte diferite. Pînă acum niciun lingvist nu a atins o asemenea poziție. Cunoaștem astfel un nou principiu al relativității, care spune că nu toți observatorii sînt ghidați de aceleași dovezi fizice spre aceeași imagine a universului, decît dacă fondurile lor lingvistice sînt similare ori dacă pot fi, într-un oarecare fel, calibrate.

Această concluzie mai degrabă surprinzătoare nu este atît de evidentă dacă este să comparăm numai limbile moderne europene, poate cu latina și greaca introduse în ecuaţie, pentru un calcul mai precis. Între aceste limbi există o considerabilă unanimitate care, la prima vedere, pare să

\footnotetext{
${ }^{10}$ Despre complexul „mecanism de glosare” al lui Whorf, v. Silverstein (2000, p. 92 seqq., 131 n. 10).
} 
confirme logica naturală. Dar această unanimitate există doar pentru că toate aceste limbi sînt dialecte indo-europene croite după același plan bazal, transmis pe cale istorică de la ceea ce a fost, cu multă vreme în urmă, o singură comunitate de vorbire; deoarece dialectele moderne împărtășesc de mult, în procesul construirii lor, o cultură comună; și pentru că o bună parte a acestei culturi, în partea mai intelectuală a ei, derivă din fundamentul lingvistic latin și grecesc. Așa se face că acest grup de limbi satisface cazul special amintit în bucata de frază care începe cu „decît dacă” în afirmația despre principiul relativității lingvistice, de la sfîrșitul paragrafului anterior. Din această condiție se naște unanimitatea descrierii lumii la comunitatea oamenilor de știință moderni. Dar trebuie subliniat faptul că „toți observatorii vorbitori de indo-europeană modernă” nu este același lucru cu „toți observatorii”.

Reținem, mai întîi, că pentru Whorf RL este un principiu, nu o ipoteză. Reținem, de asemenea, că RL este despre observații; de aici, că este un principiu metalingvistic. Pe lîngă traducere și alte mijloace de calibrare legate de traducere, reprezintă mijloace de calibrare inclusiv vorbirea despre limbi, explicarea structurii lor, aducerea la lumină a logicii lor ascunse, criptate, chiar vorbirea despre relativitatea lingvistică și despre calibrare. Relativitatea lingvistică urmărește conștientizarea lingvistică ${ }^{11}$. Aceasta este ceea ce, probabil, ar trebui să se străduiască să obțină discursul popular despre... sau orientat de relativitatea lingvistică.

Ca principiu metalingvistic, relativitatea lingvistică însăşi este un mijloc de calibrare a limbilor; și la fel este și popularizarea relativității lingvistice.

\section{Bibliografie}

Abercrombie, N. \& Turner, B.S. (1978). The Dominant Ideology Thesis, în „The British Journal of Sociology”, 29 (2), p. 149170 , Crossref.

Antoniou, M. (2019). The advantages of bilingualism debate, în „Annual Review of Linguistics”, 5, p. 395-415, Crossref.

Athanasopoulos, P., Bylund, E. \& Montero-Melis, G. (2015). Two languages, two minds: Flexible cognitive processing driven by language of operation, în „Psychological Science”, 26 (4), p. 518-526, Crossref.

Baker, A.E. \& Hengeveld, K. (eds) (2012). Linguistics, Wiley-Blackwell, Hoboken, NJ.

Benveniste, É. (1939). Nature du signe linguistique, în „Acta Linguistica”, 1 (1), p. 23-29, Crossref.

Bereby-Meyer, Y., Hayakawa, S., Shalvi, Sh., Corey, J.D., Costa, A. \& Keysar, B. (2018). Honesty speaks a second language, în „Topics in Cognitive Science”, 12 (2), p. 632-643, Crossref.

Berlin, B. \& Kay, P. (1999). Basic Color Terms: Their Universality and Evolution, CSLI Standford (1t ed.: 1991).

Björk, I. (2008). Relativizing Linguistic Relativity: Investigating Underlying Assumptions About Language in the Neo-Whorfian Literature, PhD thesis, Uppsala Universitet, Uppsala, [online].

Bock, Ph.K. (2003). World view and language, în Frawley, W. (ed.), International Encyclopedia of Linguistics, $2^{\text {nd }}$ ed., vol. 4 , p. 463-466, Oxford University Press, Oxford ( $1^{\text {st }}$ ed.: 1992).

Boroditsky, L. (2003). Linguistic Relativity, în Nadel, L. (ed.), Encyclopedia of Cognitive Science, vol. 2, p. 917-921, Nature Publishing Group, London, Crossref.

Brown, R. \& Lenneberg, E. H. (1954). A Study in Language and Cognition, în Psycholinguistics: Selected Papers by Roger Brown, p. 235-273, The Free Press, New York, 1970.

Brown, R. (1958). Words and Things: An Introduction to Language, The Free Press, New York.

Carroll, J.B. (1953). The Study of Language: A Survey of Linguistics and Related Disciplines in America, Harvard University Press, Cambridge, MA.

Cassin, B. (ed.) (2004). Dictionary of Untranslatables: A Philosophical Lexicon, translated by S. Rendall et al., Princeton University Press, Princeton.

Costa, A. (2019). The Bilingual Brain and What it Tells Us About the Science of Language, Penguin Books, London.

Darnell, R. (2001). Invisible Genealogies: A History of Americanist Anthropology, University of Nebraska Press, Lincoln / London.

Darnell, R. (2006). Benjamin Lee Whorf and the Boasian foundations of contemporary ethnolinguistics, în Jourdan, Ch. \& Tuite, K. (eds), Language, Culture, and Society: Key Topics in Linguistic Anthropology, p. 82-95, Cambridge University Press, Cambridge, Crossref.

Deutscher, G. (2010). Through the Language Glass: Why the World Looks Different in Other Languages, Henry Holt, New York.

\footnotetext{
${ }^{11}$ Lee (1996, p. 224-225) subliniază ideea că metalingvistica whorfiană este „intercalibrarea punerii în acord prin conști-
} entizare lingvistică”. 
Elffers, E. (1996). The history of thought about language and thought, in Cremers, C. \& den Dikken, M. (eds), Linguistics in the Netherlands 1996, p. 73-84, John Benjamins, Amsterdam / Philadelphia, Crossref.

Everett, C. (2013). Linguistic Relativity: Evidence Across Languages and Cognitive Domains, de Gruyter, Berlin, Crossref.

Everett, D. (2008). Don't Sleep, There are Snakes: Life and Language in the Amazonian Jungle, Profile Books, London.

Fairclough, N. (2001). Language and Power, $2^{\text {nd }}$ ed., Longman, London.

Franklin A., Drivonikou, G. V., Bevis, L., Davies, I.R.L., Kay, P. \& Regier, T. (2008). Categorical perception of color is lateralized to the right hemisphere in infants, but to the left hemisphere in adults, în „Proceedings of the National Academy of Sciences”, 105 (9), p. 3221-3225, Crossref.

Fromkin, V., Rodman, R. \& Hyams, N. (2011). An Introduction to Language, $9^{\text {th }}$ ed., Wadsworth, Belmont, CA.

Gumperz, J.J. \& Levinson, S. C. (eds) (1996). Rethinking Linguistic Relativity, Cambridge University Press, Cambridge.

Hernandez, A.E. (2013). The Bilingual Brain, Oxford University Press, Oxford.

Hill, J.H. \& Mannheim, B. (1992). Language and world view, în „Annual Review of Anthropology”, 21, p. 381-404, Crossref.

Hoijer, H. (1954). The Sapir-Whorf hypothesis, în Hoijer, H. (ed.), Language in Culture: Conference on the Interrelations of Language and Other Aspects of Culture, p. 92-105, University of Chicago Press, Chicago.

Javier, R.A. (2007). The Bilingual Mind: Thinking, Feeling and Speaking in Two Languages, Springer, New York, Crossref.

Joseph, J.E. (1996). The immediate sources of the 'Sapir-Whorf Hypothesis', în „Historiographia Linguistica”, 23 (3), p. 365-404, Crossref.

Koerner, E. F. K. (1992). The Sapir-Whorf Hypothesis: A preliminary history and a bibliographical essay, în „Journal of Linguistic Anthropology", 2 (2), p. 173-198, Crossref.

Koerner, E.F.K. (2000). Towards a 'full pedigree' of the 'Sapir-Whorf Hypothesis': From Locke to Lucy, în Pütz. M. \& Verspoor, M.H. (eds), Explorations in Linguistic Relativity, p. 1-23, John Benjamins, Amsterdam/Philadelphia, Crossref.

Koerner, E. F. K. (2002). Toward a History of American Linguistics, Routledge, London.

Labov, W. (1982). Objectivity and commitment in linguistic science: The case of the Black English Trial in Ann Arbor, în „Language in Society", 11 (2), p. 165-201, Crossref.

Lakoff, G. \& Johnson, M. (1980). Metaphors We Live By, The University of Chicago Press, Chicago/London.

Langus, A., Seyed-Allaei, S., Uysal E., Pirmoradian, S., et al. (2016). Listening natively across perceptual domains? în "Journal of Experimental Psychology: Learning, Memory, and Cognition”, 42 (7), p. 1127-1139, Crossref.

Leavitt, J. (2011). Linguistic Relativities: Language Diversity and Modern Thought, Cambridge University Press, Cambridge, Crossref.

Lee, P. (1996). The Whorf Theory Complex: A Critical Reconstruction, John Benjamins, Amsterdam/Philadelphia, Crossref.

Levinson, S.C. (2003). Space in Language and Congition: Explorations in Cognitive Diversity, Cambridge University Press, Cambridge, Crossref.

Lucy, J.A. (1992a). Language Diversity and Thought: A Reformulation of the Linguistic Relativity Hypothesis, Cambridge University Press, Cambridge, Crossref.

Lucy, J.A. (1992b). Grammatical Categories and Cognition: A Case Study of the Linguistic Relativity Hypothesis, Cambridge University Press, Cambridge, Crossref.

Lyons, J. (1981). Language and Linguistics: An Introduction, Cambridge University Press, Cambridge, Crossref.

Maier, M. \& Rahman, R.A. (2018). Native language promotes access to visual consciousness, în „Psychological Science”, 29 (11), p. 1757-1772, Crossref.

McWhorter, J.H. (2014). The Language Hoax: Why the World Looks the Same in Any Language, Oxford University Press, Oxford.

Mertz, E. (1982). Language and mind: A whorfian folk theory in United States language law, Sociolinguistics Working Paper 93, Southwest Educational Development Laboratory, Austin, TX.

Mertz, E. \& Parmentier, R.J. (eds) (1985). Semiotic Mediation: Sociocultural and Psychological Perspectives, Academic Press, Orlando, FL.

Miller, R.L. (1968). The Linguistic Relativity Principle and Humboldtian Ethnolinguistics: A History and Appraisal, Mouton, The Hague, Crossref.

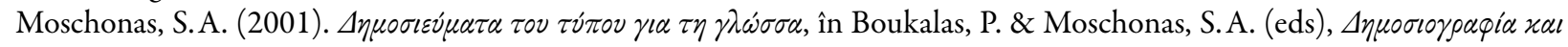

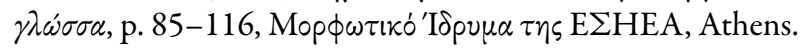

Moschonas, S. A. (2004). Relativism in language ideology: On Greece's latest language issue[s], în "Journal of Modern Greek Studies", 22 (2), p. 173-206, Crossref.

Moschonas, S. A. (2009). "Language issues" after the "language question": On the modern standards of Standard Modern Greek, în Georgakopoulou, A. \& Silk, M. (eds), Standard Languages and Language Standards: Greek, Past and Present, p. 293-320, Ashgate, London.

Moschonas, S. A. (2014). The media on media-induced language change, în Androutsopoulos, J. (ed.), Mediatization and Sociolinguistic Change, p. 395-426, de Gruyter, Berlin, Crossref.

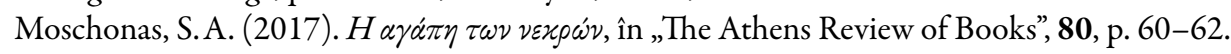

Niemeier, S. \& Dirven, R. (eds) (2000). Evidence for Linguistic Relativity, John Benjamins, Amsterdam/Philadelphia, Crossref. Pavlenko, A. (2014). The Bilingual Mind and What it Tells Us About Language and Thought, Cambridge University Press, 
Cambridge, Crossref.

Penn, J.M. (1992). Linguistic Relativity Versus Innate Ideas: The Origin of the Sapir-Whorf Hypothesis in German Thought, Mouton, The Hague, Crossref.

Pinker, S. (1994). The Language Instinct: How The Mind Creates Language, William Morrow, New York.

Pinker, S. (2007). The Stuff of Thought: Language as a Window into Human Nature, Penguin Books, London.

Pullum, G. K. (1991). The Great Eskimo Vocabulary Hoax and Other Irreverent Essays on the Study of Language, The University of Chicago Press, Chicago.

Pütz. M. \& Verspoor, N.H. (eds) (2000). Explorations in Linguistic Relativity, John Benjamins, Amsterdam/Philadelphia, Crossref.

Saussure, F. de (1995). Cours de linguistique générale, Payot, Paris ( $1^{\text {st }}$ ed.: 1916).

Sassure, F. de (2006). Writings in General Linguistics, translated by M. Pires \& C. Sanders, Oxford University Press, Oxford (French. ed.: 2002).

Schultz, E. A. (1990). Dialogue at the Margins: Whorf, Bakhtin, and Linguistic Relativity, The University of Wisconsin Press, Madison, WI.

Silverstein, M. (1985). Language and the culture of gender: At the intersection of structure, usage, and ideology, în Mertz, E. \& Parmentier, R.J. (eds), Semiotic Mediation: Sociocultural and Psychological Perspectives, p. 219-259, Academic Press, Orlando, FL, Crossref.

Silverstein, M. (2000). Whorfianism and the linguistic imagination of nationality, în Kroskrity, P.V. (ed.), Regimes of Language: Ideologies, Polities, and Identities, p. 85-138, School of American Research Press, Santa Fe, NM. / James Currey, Oxford.

Sontag, S. (1978). Illness as Metaphor, Farrar, Straus \& Giroux, New York.

Sontag, S. (1989). AIDS and its Metaphors, Farrar, Straus \& Giroux, New York.

Spitzmüller, J. \& Warnke, I.H. (2011). Diskurs-Linguistik: Eine Einführung in Theorien und Methoden der transtextuellen Sprachanalyse, de Gruyter, Berlin, Crossref.

Spitzmüller, J. (2005). Metasprachdiskurse: Engstellungen zu Anglizismen und ibre wissenschaftliche Rezeption, de Gruyter, Berlin, Crossref.

Stam, J.H. (1980). An historical perspective on 'inguistic relativity', în Rieber, R. W. (ed.), Psychology of Language and Thought: Essays on the Theory and History of Psycholinguistics, p. 239-262, Plenum Press, New York.

Suchotzki, K. \& Gamer, M. (2018). The language of lies: Behavioral and autonomic costs of lying in a native compared to a foreign language, în „Journal of Experimental Psychology: General”, 147 (5), p. 734-746, Crossref.

Thurlow, C. (2006). From statistical panic to moral panic: The metadiscursive construction and popular exaggeration of new media language in the print media, în „Journal of Computer Mediated Communication”, 11 (3), p. 667-701, Crossref.

Whorf, B.L. (1956). Language,Thought, and Reality: Selected Writings of Benjamin Lee Whorf, ed. by J.B. Carroll, The M.I.T. Press, Cambridge, Mass.

[Traducere de Adina Chirilă] 